\title{
Analyzing the Effect of Social Media Use, Perceived Value, Brand Trust and Electronic Word of Mouth on Brand Equity: The Mediating Role of Brand Image: An Applied Study on Egyptian Banking Sector ${ }^{1}$
}

\author{
Dr. AlaaEldin Abbass Ali \\ Associate Professor, Department of Business Administration \\ Faculty of Commerce, Alexandria University \\ Currently, Acting ahead of Business Administration Dept. \\ Beirut Arab University \\ alaaabass@hotmail.com
}

\begin{abstract}
The main objective of this study is to investigate factors affecting brand equity in the Egyptian banking sector. To achieve this objective, a structured questionnaire with close-ended questions is used. A two-stage sampling technique is used. First a simple random sample is used to select the banks working in Egyptian banking sector. Second a judgmental or purposive sample of different bank customers was withdrawal. In total, 400 questionnaires were distributed, 390 were used. Various statistical tools such as descriptive statistics, Cronbach Alpha, KMO, Person correlation coefficient analysis, simple and multiple regression, factor analysis was used for data analytics. The results indicated that social media use, perceived value, and brand trust have a significant positive effect on brand image in the Egyptian banking sector. e-WOM didn't has a significant influence on brand image and brand equity. Neither social media use nor e-WOM has a significant positive effect on brand equity. Brand trust and brand image have a significant influence on brand equity. Brand image mediate the relationship between social media use, brand trust, e-WOM and brand equity. This study proposed, that marketers should improve perceived value, e-WOM, social media use and brand trust in the Egyptian banking industry and they have to develop new strategies to update their current programs to reinforce both image and equity to their brand and products/services. The main contribution of this paper lies in achieving a more
\end{abstract}

${ }^{1}$ Received in 6 March 2021, accepted in 6 July 2021. 
profound understanding of the variables affecting brand equity in Egyptian banking sector, these variables include social media use, perceived value, brand trust, electronic word of mouth, and brand image.

Keywords: brand equity, social media, perceived value, brand trust, e-WOM, brand image

\section{1- Introduction}

Understanding service branding from the customer perspective is helpful for various organizations to attain a competitive edge and build a strong customer base (Ray et al., 2021). Brand equity is considered a vital tool to diagnose the relationship between consumers and brands (Han et al., 2021). Improving brand equity with companies is imperative for organizations to outperform their competitors, but the way along which consumers direct their interests has dramatically changed in the past 15 years (Tran, 2021). Enhancing brand equity is a product of effective brand building efforts that materialized into tangible and intangible benefits to the organizations (Shariq, 2019).

Introducing the products with strong brands offers the certainty of achieving quality, perceived value, trust, and a distinct place in a customer' mind. This explains why brand equity tends to ensure that a customer remains loyal to a company regardless of its price (Shabbir et al., 2017). In banking sector, and due to globalization initiatives, opportunities and advantages are being presented where it is not clear how the global banking brands will behave and compete in new emergent markets against local banks in those countries. In Egypt, the banking sector has encountered critical shifts, such as privatization, bank mergers and acquisitions (Shaalan et al., 2020). Therefore, these fluctuations have made foreign banks perceive that Egypt is a booming market, thus additional foreign banks started to enter the Egyptian banking market (Shaalan et al., 2020). The advent of new leading partners (e.g. from bank mergers) and the globalization of foreign markets are both the product of technological advances and the loosening of administrative and monetary interference that has led to intense market competition and the possibility of decreasing market shares for each banking institution (Kokkomelis, 1995). This dynamic and multinational banking environment enabled companies to concentrate their efforts on branding strategies (Lambkin \& Muzellec, 2008). 
On the research level, brand equity as a concept has been studied by several researchers and has gained a focal interest in the past three years (Sharique, 2019; Ray et al., 2021; Tran et al., 2021; Han et al., 2021; Wang et al., 2021; Algharabatet al., 2020; Veloutsoua, 2020). Various factors influencing brand equity, such as store image, speed of delivery, advertisements, promotions, consumer perceived value, e-word of mouth and brand image (Taleghani, 2011). Other research investigated congruence of personality, brand identity, brand trust and brand loyalty (Kapak \& Azizi, 2013). This research will analyze the effect of social media use, perceived value, brand trust, electronic word of mouth (eWOM) and brand image on brand equity. This research is organized in the following sequence. First, the problem statement, research importance, objectives will be summarized. Second, the theoretical background, literature review with hypotheses development and research gap will be discussed. Third, methodology, and data analysis will be presented. Finally, discussion, theoretical and managerial implication besides research limitations and ideas for future research will be briefly shown.

\section{2-Problem Statement}

Generally, in a world of increasing brand globalization, it is critical to evaluate the value of a brand against its global competitors (Han et al., 2021). While services companies are striving to enhance their brand equity due to the intangibility dilemma of their market offering, it's difficult for the customers to perceive the promising services (de Chernatony \& Segal-Horn, 2001). Additionally, customers' perceptions of the service products are not only relying on what they are going to get but, on the way, they will obtain (Grönroos, 1990). Thus, weak relationships between service companies and their customers will undermine the efforts to build brand equity. In the banking sector, although it is important to build strong brand equity, banks have a negative brand perception (Ferguson \& Hlavinka, 2007).

Moreover, to maintain their operational viability, banks are still under pressure to raise service prices, but bank consumers have a strong aversion to price rises and may switch their banks as a result of these actions (Deloitte, 2013). Nonetheless, consumers will be able to pay 
more for a brand that provides higher perceived benefits (Priem, 2007). Multinational banks that have penetrated emerging markets have lacked guidelines on the most efficient strategies to build brand equity and how to compare their performance with that of national operators (Pinar et al., 2012; Elsharnouby \& Parsons, 2010).

On the research level, literature lacks good insights into brand equity in developing countries generally an in Egypt in particular. International banks that have expanded into emergent markets have lacked guidance on building efficient strategies for brand Equity (Shaalan et al., 2020). In marketing literature, brand equity has been significantly deliberated (Aaker, 1991; Keller, 2001; Lee et al., 2015; Chatzipanagiotou et al., 2016; Mohan et al., 2017; Sharique, 2019: Ray et al.2021; Tran et al., 2021; Han et al., 2021; Wang et al., 2021; Algharabatet al., 2020; VeloutsouCas, 2020) which draws the various viewpoints on the factors that impact brand equity. Undeniably, when it comes to the conceptual foundations influencing the factors and measures of brand equity, and academic debate is characterized by uncertainty (Davcik, 2013). Relationship marketing, branding, and retailing literature demonstrate the existence of a vital relationship between trust and satisfaction (Caceres \& Paparoidamis, 2007; Christodoulides et al., 2015). According to Kumar et al., (2013) brand trust and satisfaction, usually produce brand reliability. Therefore, since satisfaction and trust are accountable for developing a relationship (Fuentes-Blasco et al., 2017), it progresses to an incline in the value of that relationship (Moisescu \& Allen, 2010). The current literature on branding is indicative of the thought that brand trust is centered on consumer-brand relationships (Sheth \& Parvatiyar, 1995).

In Egypt, banking sector has undergone profound changes, specifically after reforming programs in the 1990s, which resulted in a reduction in the number of banks operating in the country from 62 to 39. These changes lead to encourage international banks to penetrate the Egyptian market. The findings demonstrated fierce competition and major improvements like the relationships between banks and their consumers. This competition enforces national banks in Egypt to improve and strengthen their brand equity (Shaalan et al., 2020). On the research level also, researchers pointed out that brand equity as a concept and factors which predict it are far from simple, and there is a 
little agreement on the specific dimensions that capture it. However, most research recognizes that brand equity consists of numerous interrelated dimensions and the literature supports the need to approximate brand equity more comprehensively (Veloutsou et al., 2020).

In this research, a pilot study was conducted to clearly understand and validate the research problem. As well as to develop the research question on factors affecting brand image and brand equity in Egyptian banking sector. The main objective of this pilot study is to uncover the current research problem, concerning the difficulties facing the consumers 'in perceiving both brand image and brand equity. Whereby the pilot study sample consists of 50 banks' customers in Alexandria, Egypt. This pilot study adopted judgmental sampling technique. Whereby, Face-to-face interviews have been conducted. The pilot study findings revealed that the customers are facing difficulties in comprehending brand image and consequentially brand equity for their banks. Also, the results indicated that many factors might influence the brand image and equity for Egyptian banks. Such as; social media use, customers' satisfactions, perceived value, brand trust, customers' loyalty, and e-WOM. Hence, this pilot study finding supported the current research problem. Thus revealing the possibility of applying a research on large scale to analyze the factors affecting brand image and equity.

Based on the aforementioned dissection, the research problem of the study is summarized in the following main question: what are the factors affecting brand equity? The subset questions to describe the research problem will be presented as follows: (1) what is the effect of social media use on a brand image? (2) what is the effect of perceived value on a brand image? (3) what is the effect of a brand trust on brand image? (4) what is the effect of e-WOM on a brand image? (5) what is the effect of social media use on brand equity? (6) what is the effect of brand trust on brand equity? (7) what is the effect of e-WOM on brand equity? (8) what is the effect of brand image on brand equity? (9) what is the mediating role of brand image on the relationship between social media use and brand equity? (10) what is the mediating role of brand image on the relationship between brand trust and brand equity? (11) what is the 
mediating role of brand image on the relationship between e-WOM and brand equity?

\section{3- Research Importance}

The importance of this research is classified into academic or theoretical importance and practical importance. On one side the main academic or theoretical importance of this study is to close the research gap after reviewing the literature review. Second, this study will contribute to the marketing literature on the concept of brand equity in the banking sector by developing a conceptual framework that included four variables that help in explaining this concept from a customer perspective. Third, this study is considered as one of the few empirical studies in Egypt, which contributes to understanding brand equity through analyzing the role of social media use and e-WOM. Forth, the study contributes to better understand brand equity by examining the mediating effect of brand image on the relationship between brand trust, e-WOM and brand equity. On the other side, this study has several managerial contributions. First, the results of the study contribute to help managers in the banking sector to enhance, support and strengthen the brand value of their organizations. Second, this study introduces concrete suggestions to exploit the widespread of social media use and e-WOM as a tool to improve both brand image and brand equity in the banking sector. Third, the results and managerial contributions of this study will guide managers in financial institution sector to improve their competitive position by concentrating on the interplaying role of perceived value, brand trust, e-WOM, and brand image.

\section{4- Research Objectives}

4-1 This research is aiming to achieve the following objectives:

4-2 To study the effect of social media use on brand image in the Egyptian banking sector.

4-3 To analyze the effect of customer perceived value on brand image in the Egyptian banking sector.

4-4 To analyze the effect of brand trust on brand image in the Egyptian banking sector. 
4-5 To investigate the effect of e-WOM on brand equity in the Egyptian banking sector.

4-6 To analyze the effect of social media use on brand equity in the Egyptian banking sector.

4-7 To analyze the effect of brand trust on brand equity in the Egyptian banking sector.

4-8 To study the effect of e-WOM on brand equity in the Egyptian banking sector.

4-9 To analyze the effect of brand image on brand equity in the Egyptian banking sector.

4-10 To test the mediating role of brand image between social media use and brand equity in the Egyptian banking sector.

4-11 To analyze the mediating role of brand image between brand trust and brand equity in the Egyptian banking sector.

4-12 To analyze the mediating role of brand image between e-WOM and brand equity in the Egyptian banking sector.

4-13 In the coming part, the theoretical background will be discussed briefly in order to provide profound clarification to answer the research question.

\section{5- Theoretical Background}

This part will discuss a summary of the main theories in explaining brand equity and the conceptualization of the variables used in this research.

\section{5-1 Theories in Explaining Brand Equity}

Most of the studies in brand equity were based on Stakeholder Theory, Social network Theory, and Commitment -Trust Theory. In the next part, the researcher will briefly shed the lights on these theories.

\section{5-1-1 The Stakeholder Theory}

This theory stated that, in addition to protecting their own interests, banks are committed to protect the interests of their stakeholders which include their consumers, employees, shareholders and communities (Tran et al., 2021). Consequently, as a relational market-based asset, the examination 
of brand equity should include analyzing the relationships with other members of the value chain, counting employees (especially in-service companies), investors, or even suppliers. Besides, within stakeholders' a firm possibly build up solid brand equity based on the relationships established with consumers. In other words, answering the following questions will help in improving a firm's brand equity: to what extent does brand equity depend on relationships with stakeholders' groups rather than the focus group which is the consumers? To what extent is it important to manage each relationship? Is trust the most valued aspect in all relationships? If that is the case, then, how is trust defined? (Friedman, 2006).

\section{5-1-2 Social Network Theory}

Social network theory focuses on the role of social relationships in transmitting information, channeling personal or media influence, and enabling attitudinal or behavioral change. Since the 1960s, social network theory has significantly expanded the horizon of media effects research, with increasing application of network analytic methods in various empirical contexts. The two-step flow of communication hypothesis, the theory of weak ties, and the theory of diffusion of innovations are three major theoretical approaches that integrate network concepts in understanding the flow of mediated information and its effects (Juma \& Khalid, 2021).

\section{5-1-3 Commitment - Trust Theory}

According to relationship marketing, for a relationship to be considered successful, two vital factors should exist which are trust and commitment. Relationship marketing encompasses establishing bonds with customers by achieving their needs and fulfilling commitments. And instead of pursuing short-term profits, businesses should build long lasting bonds with their customers. Hence the result will be customers that trust these businesses and a reciprocated loyalty which will aid both parties in their goal to achieve their needs (Morgan \& Hunt, 1994).

\section{5-2 Variables Conceptualization}

Concerning the research problem and objectives, variables conceptualization in this study will be briefly discussed in the next part. 
These variables include brand equity, social media use, perceived value, brand trust, e-WOM, and brand image.

\section{5-2-1 Brand Equity}

Although several different definitions of brand equity have been proposed, it is widely accepted that brand equity refers to the 'added value' endowed on goods because of past investment in that brand (Han, et al., 2021). Brand equity is defined also as the difference between consumers' responses to a focal brand and an unbranded product when both have the same level of marketing stimuli and product attributes" (Algharabat et al., 2020). Brand equity gives deep benefits to the organizations by growing the efficacy of the marketing campaigns. Brand equity components make it possible for an organization to gain a competitive edge over other competitors. This leads to higher price earnings ratios, and improved shareholder returns, achieved as a result of customer brand loyalty (Padhy \& Sawlikar, 2018). Further, Aaker has investigated which factors define a strong brand, and concluded that brand awareness, brand associations, perceived quality, and brand loyalty have a strong impact on the value of the brand, as he laid the foundation for how other scholars have discussed these four factors (Aaker, 1992). Brand equity can be analyzed from three different points of view: Financial-based Brand Equity (FBBE), Employeebased Brand Equity (EBBE) and Customer-based Brand Equity (CBBE) (Han et al., 2021). The FBBE represents the value of a firm which is based on the aggregated earning-power of both its tangible and intangible assets (Baalbaki, 2012). Simon \& Sullivan, (1993) define FBBE as the incremental cash flows, which accrue to branded products over and above the cash flows which would result from the sale of unbranded products (Simon \& Sullivan, 1993). EBBE is defined as, "the differential effect that brand knowledge has on an employee's response to their work environment “(King \& Grace, 2009).

During the last decades, brand equity has been modified and generated from different viewpoints. For instance, the model generated by Atilgan et al., (2009) "other proprietary. brand assets with brand trust. Atilgan et al., (2009) model has also been modified by Serveri \& Ling (2013) from brand trust to brand image and they define the dimensions of brand equity as brand awareness, brand associations, brand loyalty, brand image and 
perceived quality. CBBE's definition is made up of brand awareness, brand loyalty, brand associations, perceived quality and other proprietary assets (Aaker, 1992). The fifth dimension of CBBE is of the least importance according and is only included to complete the model. Other proprietary assets include patents, trademarks and other channel relations. These assets could be important if a company wants to grow and extend its brand (Kale et al., 2000). Thus, consumer-based brand equity models have been developed to approach brand equity from the perspective of consumers, and this encompasses a consumer's perceptions and feelings about the advantages that the branded product or service offers (Han et al., 2021). Furthermore, this study will focus on the four main brand equity dimensions, namely brand awareness, brand associations, brand loyalty, and perceived quality.

\section{5-2-2 Social Media Use}

Social Media provides attractive opportunities for services companies to enhance their brand and to connect their customers (Swani et al., 2021). Social network sites, as web-based services allow individuals (1) to build a public or semi-public profile within a bounded system, (2) to draw up a list of other users with whom they share a connection, and (3) to view and pass through their list of connections and those made by others within the system (Boyd \& Ellison, 2008). Social media is defined as "manifestations from customers toward a firm or a brand beyond purchase", motivated by social media affordances (Castillo, et al., 2021). Furthermore, in her study on the importance of company social media activity in comparison to consumers and enterprises, Lee (2017) categorize ' social media activities into communication, providing information, supporting everyday life, promoting and selling and social action. After social media are defined, companies need to know how to use them to their benefit. Social media marketing enhances traditional marketing, by employing social media instruments (Zahoor \& Qureshi, 2017).

\section{5-2-3 Perceived value}

Generally, perceived value has been recognized as one of the most important factors for understanding consumers in the area of commercial and marketing (Pang, 2021). Perceived value is the overall utility value of a product or service that a consumer perceives based on a cost-benefit 
trade-off (Singh et al., 2021). Value is analyzed in terms of what customers pay and what they get in return (Sweeney \& Soutar, 2001). perceived value can be categorized into five main dimensions. functional value, conditional value, emotional value, social value, and ultimately epistemological value (Sheth et al., 1991). (1) Functional value is considered the objective to purchase; (2) Conditional value is perceived benefit gained in a particular situation. It reflects the circumstance in which some market choices are dependent on the particular situation faced by the consumers of a product or service (Sheth et al., 1991). Meanwhile, Ehsani \& Hashim (2015) argued that conditional values are appropriate to measure customer perceived value. however, (3) emotional value is passion produced for just a specific brand (Woodruff, 1997). (4) social value is the acceptability of consumers' relationship with the social environment. social value refers to social agreement and enrichment of one's image in the society (Singh et al., 2021). Finally, (5) epistemic value is defined as "The capacity of the product or service to satisfy the desire for knowledge". Epistemic value refers to novelty value as well as the value gained from learning a new way of doing things such as experience or knowledge gained through testing or exploring new services. Nevertheless, in this study, the aim is to focus on the overall customer perception toward the value. Perceived value refers to consumers' overall perceptions of the costs and benefits associated with a consumption experience (Ashraf et al., 2021). Generally, the definition of perceived value inclines to vary relying on the modes of particular commercial products or services (Pang, 2021).

\section{5-2-4 Brand Trust}

Trust is a mechanism for the reduction of complexity; therefore, it enables people to maintain their capacity to act in a complex environment. At the same time, trust is needed to construct a more complex technical and social environment (Siegrist, 2021). Customer trust is considered as a crucial factor in developing consumer-brand relationships (Li et al., 2020). Nowadays practitioners and researchers have taken an increasing interest in brand trust. Customer trust refers also to the committed and personal bond between customers and a brand (Li et al., 2020). Generally, "Trust is a psychological state comprising the intention to accept vulnerability based upon positive expectations of the intentions or behavior of another" (Seigrist, 2021). 


\section{5-2-5 Electronic-Word of Mouth (e-WOM)}

The influence of word-of-mouth (WOM) has grown drastically as a result of the proliferative use of smart electronic devices and online information sharing platforms (Wang et al., 2021). Messages spread to influence people in positive or negative ways. Word of Mouth (WOM) refers to an informal and personal communication with no commercial purpose regarding brands, products, or organization (Wang et al., 2021). It is also defined as interpersonal communication regarding the evaluation of products or services of interest. Based on Gheorghe \& Liao (2012), word of mouth communication is the interchange of information between what is considered as a traditional interpersonal information source like friends, family, and acquaintances about products, services, and companies

\section{5-2-6 Brand Image}

brand image is perceived as an important variable in enhancing marketing strategy and help managers to alter potential marketing endeavors (Mitra \& Mamata, 2020). Brand image is defined as the perception present in the consumers' memory, in terms of a network of associations (Mitra \& Mamata, 2020). Brand image can be perceived as emotion, which, being an intangible asset of the company, ensures its long-term prosperity (Išoraitè, 2018). Aaker (1991) defines brand image as a "set of brand association that is anything linked in memory to a brand, usually in some meaningful way". In reviewing marketing literature, perceptions of brand image are varying. Sometimes brand image is considered as a part of a process, other times is associated as emotions and elsewhere is understood as information disseminated by organizations (Išoraitè, 2018).

\section{6- Literature Review and Hypotheses Development}

To achieve the research objectives, the researcher will rely on a narrative literature review, which helps in summarizing the literature body, developing conclusions concerning the studied topic, and uncover the literature gaps. Furthermore, the narrative review's main concern is devoted to the research question (Machi \& McEvoy, 2016). In the coming part, research will focus on the key variables that affect brand equity. Variables affecting brand equity are social media use, perceived value, brand trust, electronic word of mouth, and brand image. 


\section{6-1 The Relationship between Social Media Use and Brand Image}

Sanny et al., (2020) analyzed the relationships between social media use, brand image and brand trust on purchase intention of Indonesian Male's Skincare. The study used a quantitative approach of non-probability sampling technique to collect the data from 203 male respondents. The results revealed that social media use is significantly affect brand image and brand trust.

The viral effect among social media users allows the brand to be discussed and widely known among a large number of users (Kumar et al., 2016). In recent years, research about brand communities and social media became increasingly essential. According to Graves (2016), data acquired from social media offers a useful understanding of brand perceptions, or assist in generating more effective strategies. For example, it is conceivable to screen and scrutinize the brand in real time in numerous ways by utilizing data from social media or to "scan and interpret" the posts made by social media users allowing the designing of marketing campaigns that are precisely targeted based on the segmentation of audiences on profound levels (Graves, 2016). Based on all the above, Formulated hypotheses is as following:

H1: Social media use has a significant positive effect on brand image in the Egyptian banking sector.

\section{6-2 The Relationship between Perceived Value and Brand Image}

Studies have a lot of variances, debate, and contradiction in analyzing the nature of the relationship between perceived value and brand image. While some research stated that brand image affects perceived value (Lai et al., 2009), other research stated that there is no relationship between the variables (Andreassen \& Lindestad, 1998) and different research stated that perceived value affects brand image (Barich \& Kotler, 1991).

Cretu \& Brodie (2007) have stated that in a business market, brand image is associated with customer perceived value. They explored the influence of brand image and company reputation on customers' perceptions of product and service quality, customer perceived value, and customer loyalty. Also, Andreassen \& Lindestad (1998) also examined in a service 
context the relationship between customer perceived value and store/corporate image. The results showed that there was no significant relationship between image and customer perceived value even though the corporate image affected outcome variables like perceived satisfaction and quality. Setini et al. (2020) pointed out that perceived value is affect brand image. In the same direction, Hsieh, (2016) conducted a study to analyze the debatable relationship between customer perceived value and brand image. The study surveyed 300 respondents in Taiwan chain tea drink stores market. The findings revealed that customer perceived value is positively affect brand image. The study indicated also that Brand image did not have significant effects on perceived value. therefore. given all the above, our formulated hypothesis is as following:

H2: Perceived value has a significant positive effect on brand image in the Egyptian banking sector.

\section{6-3 The Relationship between Brand Trust and Brand Image}

Many researchers have stated that brand image is affected by customer trust (Esch et al., 2006; Hadinata, 2021) since when customers experience deep trust for a certain brand, the brand is most likely to be imprinted in their mind (Hyun \& Wansoo, 2011). Deheshti et al. (2012) have explored the relationship between foreign brand image and trust among buyers of foreign sports brands, and the results indicated that there is a significant relationship between the two variables. Hadinata, (2021) conducted a study motivated to investigate the relationship between perceived quality, brand image, brand trust and brand loyalty. Data collection techniques used questionnaires with a number of 130 valid responses collected. The results showed that brand image has a positive significant effect on brand trust, perceived quality has a positive significant effect on brand image, perceived quality has a positive significant effect on brand trust, brand trust has a positive significant effect on brand loyalty, perceived quality has a positive significant effect on brand loyalty mediated on brand trust and brand image has a positive significant effect on brand loyalty mediated on brand trust.

A study performed by (Song et al., 2019) to investigate the relationship between brand image and brand trust using 401 piece of data applied on coffee shop industry in South Koria pointed out that brand trust is 
significantly affect brand image. Among 286 students from the Institute of Business Administration, Alhaddad (2015) have applied a structural equation model to examine the relationship between brand image, trust, and loyalty, the results indicated that there is a significant relationship between brand trust and brand image. Nazari et al. (2015) indicated that there is a substantial positive relationship between green brand image, trust, green brand perceived quality, green brand loyalty, and green brand awareness. However, there is a shortage of research that examines the effect of brand trust on the brand image; therefore, given all the above, the formulated hypothesis is as following:

H3: Brand trust has a significant positive effect on brand image in the Egyptian banking sector.

\section{6-4 The Relationship between Electronic Word of Mouth and Brand Image}

Siddiqui et al. (2021) analyzed the effect of e-WOM on brand image. Data was collected from 256 respondents, using both offline and online modes from 4 different cities of India. The results indicated that e-WOM positively affected brand image. Chevalier \& Mayzlin (2006) explored the impacts of online product reviews on relative sales of two online bookshops. The findings indicated that online communications considerably influence other consumers' purchase behavior. However, the rich literature on the effects of e-WOM on purchase intention, no research has been conducted to investigate which e-WOM has strong effects on brand image. e-WOM has been discovered as one of the most useful factors that impact brand image and brand equity in consumer markets (Jalilvand \& Samiei, 2012). A study conducted in Bangkok-the capital of Thailand-using 403 respondents of hotel customers revealed that e-WOM is positively affect brand image (Plidtookpai \& Yoopetch, 2021). Given all the above, formulated hypothesis is as following:

H4: e-WOM has a significant effect on brand image in the Egyptian banking sector. 


\section{6-5 The Relationship between Social Media Use and Brand Equity}

Generally, social media plays a significant role in building and maintaining brand equity (Algharabat et al., 2020). A study conducted by (Stojanovic et al., 2018) to analyze the effect the intensity of use social media on brand equity. study population were international tourists, over 18 years of age, who were visiting the city of Valencia, Spain. Respondents were asked to take the questionnaire upon arrival in Valencia, that is, before they had any direct experience of the tourist destination and when their knowledge of the city came only from the sources of social media information they have used. The final sample size was 249 interviewees. Findings indicated that social media use is positively affect brand equity.

The interaction of customers about the brands through social media will positively contribute to brand equity (Algharabat et al., 2020). Various studies emphasized the association between social media marketing and brand equity. A study done by Odhiambo (2012) utilized a case study research to investigate the effect of social media compared with the traditional media on brand equity. The findings revealed that social media is more efficient than traditional media affecting brand equity. Besides, a study done in Sri Lanka as a destination for international tourists has examined the influence of social media marketing on the making of brand equity, and it resulted in the fact that factors that are considered as social media marketing efforts like entertainment, customization, and e-WOM positively influence the brand equity of Sri Lanka as a destination for international tourists (Hilal, 2019). However, considering the sizeable scale of social media usage, there is a shortage of research that investigates the impact of various social media on brand equity (Gürhan-Canli et al., 2016; Keller, 2016). Therefore, the following hypothesis will be proposed:

H5: Social media use has a significant positive effect on brand equity in the Egyptian banking sector.

\section{6-6 The Relationship between Brand Trust and Brand Equity}

Brand trust has an active role in the development process of brand equity. Usually, brand trust is developed from previous experience and interaction (Garbarino \& Johnson, 1999). Most often, the evolvement of brand trust is 
depicted as an individual's experiential process of learning that occurs over time. Nguyen \& Tuan (2021) conducted a research using qualitative approach via focus group through direct interviews with 477 consumers. The findings revealed that brand trust affect brand equity. The results revealed that green brand image, green satisfaction, and green trust are favorably correlated to green brand equity (Taghipourian \& Saberi, 2021). Brand trust is a variable that has obtained broad attention from researchers to evaluate customer-based brand equity (Kumar et al., 2013). Brand satisfaction remains to be well-researched and there exists a common understanding that brand satisfaction positively influences brand equity (Pappu \& Quester, 2006). The results imply that there is a robust favorable relationship between brand trust and brand relationship (Chaudhuri \& Holbrook, 2001) and that brand trust impact brand equity (Delgado-Ballester \& Munuera- Aleman, 2005). Given all the above, Formulated hypothesis is as following:

H6: Brand trust has a significant effect on brand equity in the Egyptian banking sector.

\section{6-7 The Relationship between Electronic Word of Mouth and Brand Equity}

Bambauer \& Mangold (2011) have explored factors that affect consumerbased brand equity such as negative online product reviews, a specific type of word-of-mouth communication, their findings advocated the presumed unfavorable effect of negative online product reviews on consumer-based brand equity. Furthermore, after investigating the impact of e-WOM on brand equity, it was found that e-WOM positively influences brand equity. Sagynbekova et al. (2021) have investigated the effect of e-WOM on brand equity using data solicited from 317 university students in Cyprus. The results indicated that e-WOM is significantly affect brand equity. Given all the above, Formulated hypothesis is as following:

H7: e-WOM has a significant effect on brand equity in the Egyptian banking sector.

\section{6-8 The Relationship between Brand Image and Brand Equity}

Prior researchers have indicated that brand equity is directly affected by brand image (Ansari \& Hashim, 2018; Jaiprakash, 2008). Moreover, the 
work of Aaker (1991) and Keller, (1993) considering the effect of brand image on brand equity. The results indicated that brand equity can be manipulated at the independent construct level by providing specific brand associations or signals to consumers and that these associations will result in images and that influence brand equity. Accordingly, brand image is one of the most significant factors that build brand equity. Previous studies (e.g., Ansari \& Hachem, 2018; Jaiprakash, 2008) have shown that brand image has a direct effect on brand equity. Hence, given all the above, Formulated hypothesis will be as following:

H8: Brand image has a significant effect on brand equity in the Egyptian banking sector.

\section{6-9 The Mediating Role of Brand Image}

A few numbers of researchers have investigated the mediating effects of brand image on the relationship between social media use, perceived value, brand trust, e-word of mouth, and brand equity. Identifying mediating effects is necessary, as it will enable scholars to understand whether differential relationships arise according to identifiable portions of their sample (Bryman \& Cramer, 2002). A good communicative brand image should help build brand positioning, differentiate it from competing brands, and also enhance the brand's performance in marketing, and as a result can eventually build a long-term connection between brand and consumers (Keller, 2001). A company's marketing activities can cause a cumulative impact on consumer's perceived brand image. Thus, brand image is expected to play a mediating role between all activities related to branding. In the coming part, this mediating role will be elaborated briefly.

6-9-1 The mediating role of brand Image between social media use and brand equity

Nowadays, social media sites are the most popular type of online brand communities (Chattopadhyay et al., 2010). The term social media is used for all forms of electronic communication in which companies and consumers take an active part. Social media stands for "global, open, transparent, non-hierarchical, interactive communication that is carried out in real time and changes consumer behavior and business expectations" (Chattopadhyay et al., 2010). Nowadays firms deem social 
media advertisements produce similar positive outcomes as traditional advertisements, and that it is easier and quicker to communicate with consumers, hence it allows companies to transfer positive brand images (Seo \& Park 2018). So social media impacts brand image, and social media impacts brand equity. Also, brand equity is directly influenced by brand image (Ansari \& Hachem, 2018). Therefore, it is proposed that brand image mediates the relationship between social media and brand equity, thus the following hypothesis is suggested:

H9: Brand image mediates the relationship between social media use and brand equity in the Egyptian banking sector.

\section{6-9-2 The Mediating Role of Brand Image between Brand Trust and Brand Equity}

Previous research demonstrated that brand image can be used as a partial mediator variable between brand trust and equity (Alhaddad, 2015; Ansary \& Hashim, 2018). Besides, some scholars investigated factors that affect brand image, which include: price, after sales service, personality, social image, positioning, relationship, location, country of origin, and staff. All of these factors are belonging to brand image attributes, and brand awareness, consumer attributes, as the three sub-component that directly affect brand equity, (Mourad et al., 2010). Also, Hou \& Wonglorsaichon (2015) in their study found that brand awareness is positively related to brand trust, brand trust is positively related to brand equity. Therefore, it is proposed that brand image mediates the relationship between brand trust and brand equity, thus the following hypothesis is suggested:

H10: Brand image mediates the relationship between brand trust and brand equity in the Egyptian banking sector.

\section{6-9-3 The Mediating Role of brand Image between e-WOM and Brand Equity}

e-WOM is a prominent marketing tool for firms since before buying products or services, consumers tend to search online for reviews displayed by prior consumers (Pitta \& Fowler, 2005). Also, an important aspect of e-WOM is that brand image and consumer's perception can be greatly impacted by the electronic word of mouth via social media networks (Jansen et al., 2009). Alam \& Khan (2015) research has 
presented a prominent groundwork for comprehending the influence of social media on brand equity. They have examined brand equity dimensions to discover these dimensions are correlated to e-WOM, and how these dimensions can add to the general brand equity. The outcome indicated that e-WOM has a considerable effect on brand equity. Besides, a study done in the context of social media explored what role does brand loyalty, brand association, brand awareness, and brand image perform in mediating the interrelationship between electronic word of mouth and brand loyalty, brand association, brand awareness, and brand image. The outcome indicated that there exists an indirect interrelation among electronic word of mouth and the dimension of brand equity, mediated by brand loyalty, brand association, brand awareness, and brand image (Severi et al., 2014). Thus, based on the aforementioned discussion, the mediating relationship of the brand image between e-WOM and brand equity is proposed in the following hypothesis:

H11: Brand image mediates the relationship between e-WOM and brand equity in the Egyptian banking sector.

\section{6-10 Research Gap}

Based on the aforementioned literature review, this study will bridge three main research gaps. These gaps will be summarized as follow: First, there is no consensus on the type of relationship between perceived value and brand image. On one side, regarding the relationship between a couple of variables, some research revealed that brand image is considered an independent variable (Lai et al., 2009; Ryu et al., 2008). On the other side, some research revealed that perceived value is considered an independent variable (Lai et al., 2009; Cretu \& Brodie, 2007). Second, although the majority of marketing literature that examined brand equity analyzed the concept from financial, employees, and customer perspectives, few studies investigated the vital role of social media use and e-WOM in building and enhancing strong brand equity. Thus, a literature gap exists which impedes understanding the vital role played by social networking sites to strengthen brand equity. So, many research are required to comprehend this role. Third, although many studies analyzed the relationship between social media use, perceived value, brand trust, e-WOM, brand image, and brand equity, few studies have been conducted to investigate the interplay 
relationships between these variables in the context of the Egyptian banking sector.

\section{7- Research Methodology}

In this part, conceptual research framework, questionnaire development, population/sample and data description will be presented briefly. The analysis leading up to the results will be discussed. The research methods used in this study can be divided as follows:

\section{7-1 Proposed Conceptual Model}

This figure shows the proposed conceptual framework for factors influencing brand equity

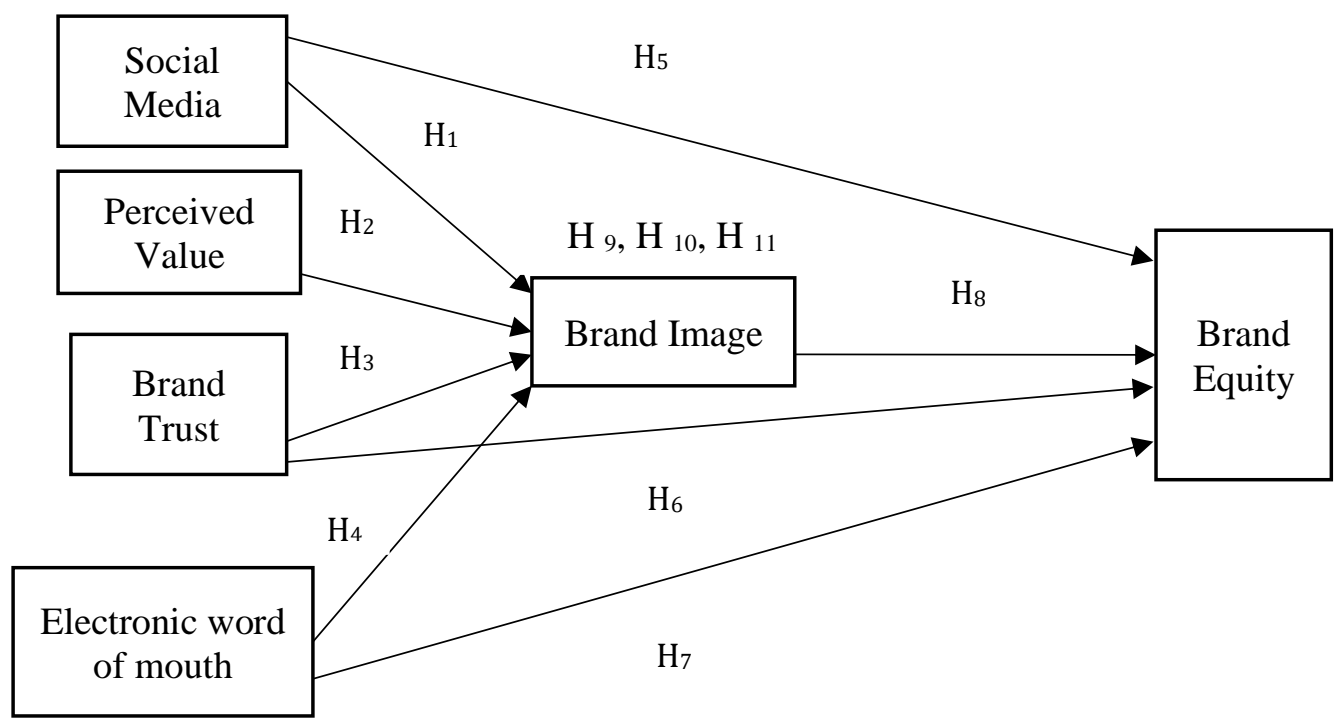

Figure I: Proposed conceptual Framework

\section{7-2 Population and Sample}

In the coming part a brief description to the research population and sample will be highlighted as follow:

\section{7-2-1 Research Population}

Egyptian banking sector is consisting of 40 banks categorized as commercial, non-commercial public and private sector according to the central bank of Egypt, 2021(www.cbe.org.eg). Although there are a few specialized banks (i.e. agriculture and real estate) but practically the vast 
majority of banks working in Egypt are considered as commercial banks. The National Bank of Egypt, Bank Misr, and Banque Du Caire are large public-sector banks which control 40 percent of the banking sector. All banks in Egypt are subject to supervision by the CBE (central bank of Egypt); however, the Arab International Bank, Nasr Social Bank and the National Investment Bank are exempted due to special provisions in law and treaty. Citibank, formerly the only full-service American bank operating in the Egyptian market, sold its consumer and retail operations to CIB bank, though it maintains its commercial and investment banking operations in Egypt (www.privacyshield.gov). To achieve the research objectives, this study defined the population as all of the Egyptian bank customers who have bank accounts for at least one year. The study focused on Egypt. specifically, in the Alexandria area which is the secondlargest city in Egypt and a major economic center.

\section{7-2-2 Research Sample}

In this research, two stage sampling technique is used. The first stage is aimed to select the banks using convenience non probability sampling technique. Sampling frame used is the list of banks registered by the central bank of Egypt. Convenience sampling is selected due to time, effort and budget constraints. Whereby, the first stage includes nineteen out of thirty-nine banks working in Alexandria city. In the second stage, the researcher also adopted the convenience sampling technique, as a base to select the research respondents. Whereby, the reason for adopting convenience sampling technique is the time, effort and research budget constraints. The unit of the study is bank equity, while the sample units were classified according to the banks they are affiliated to as shown table (1). The researcher adopted the convenience method as a base to allocate the sample units on the selected banks. Regarding the sample size, Krejcie and Morgan (1970) demonstrated that the minimum accepted sample size for any open population is equal 384 units. Relatedly, Sekaran and Bougie (2016) illustrated that 384 respondents are the minimum accepted sample size, for population which includes more than 75000 units. Table (1) showing the distribution of the research respondents according to the bank. 
Table 1: The distribution of the research respondents according to the bank

\begin{tabular}{|c|l|c|}
\hline $\mathbf{N .}$ & \multicolumn{1}{|c|}{ Banks } & $\begin{array}{c}\text { Number of } \\
\text { Respondents }\end{array}$ \\
\hline 1 & Banque Misr & 108 \\
\hline 2 & National Bank of Egypt & 95 \\
\hline 3 & Bank of Alexandria & 33 \\
\hline 4 & Banque Du Caire & 29 \\
\hline 5 & Commercial International Bank (Egypt) & 21 \\
\hline 6 & Faisal Islamic Bank of Egypt & 15 \\
\hline 7 & Societe Arabe Internationale de Banque & 14 \\
\hline 8 & Blom Bank - Egypt & 11 \\
\hline 9 & Emirates National Bank of Dubai S.A.E. & 11 \\
\hline 10 & Suez Canal Bank & 9 \\
\hline 11 & Agricultural Bank of Egypt & 8 \\
\hline 12 & Qatar National Bank Alahli S.A.E & 7 \\
\hline 13 & Arab Investment Bank & 6 \\
\hline 14 & Housing and Development Bank & 6 \\
\hline 15 & Ahli United Bank - Egypt & 5 \\
\hline 16 & National Bank Of Kuwait - Egypt (NBK) & 3 \\
\hline 17 & Abu Dhabi Islamic Bank - Egypt & 3 \\
\hline 18 & Egyptian Gulf Bank & 4 \\
\hline 19 & Arab Bank & 2 \\
\hline & Total & 390 \\
\hline
\end{tabular}

Source: the researcher

\section{7-3 Data Collection Procedures and Questionnaire Development}

Structured questionnaire is used as a method for data collection. Respondents were asked about if they have a banking account, making more than one banking transactions and also if they have a reasonable degree of knowledge, opinions, and feelings toward the bank. When their answers were proved that they have the independence and the experience sufficient, permission was invited to participate in filling the questionnaire (Edwards, 1990). In order to make sure that the respondents better understand of the questionnaire statements, the researcher relied on face to face interviews via using the intercept technique as a data gathering method while they are awaiting to get their banking services. To reduce the sample bias of the judgmental or purposive sample, the researcher tried to diversify the sample characteristics, the time for data gathering, banks, the branches of banks 
selected. Out of 400 questionnaires were distributed 390 useable responses collected were yielding a useable response rate of $97.5 \%$. Data gathering processes took seven months between January and August 2020 by the researcher himself and assistants to help and motivate the respondents to fill the questionnaire.

Questionnaire was developed with closed-ended questions based on 7 Point-Likert scale ranging from strongly agree to strongly disagree. The questionnaire in English was translated into Arabic. It contains 23 questions divided into two sections. The First part is the demographics and consists of questions about gender, marital status, education level, and income. The second part contains questions concerning the independent, mediated, and dependent variables as follows: social media use "4 item scales" (Ismail et al., 2018), a Perceived value "7 item scales" (Hasan et al., 2014), Brand trust "4 item scales" (Chaudhuri \& Holbrook, 2001), e-WOM "3 item scales" (Seo \& Park, 2018), Brand image "3 item scales" (Seo \& Park, 2018), Brand equity "4 item scales" (Rambocas \&Vishnu 2014).

\section{7-4 Statistical Tools}

Various statistical tools have been used in this research, descriptive statistics to describe the basic profile of respondents who shared in the study. Cronbach's Alpha is used as a measure of instrument internal consistency (lee, 2004). Simple and multiple regression will be used to test hypotheses by testing a single independent on the independent variable to predict the value of the dependent variables relying on SPSS version 25 . The data analysis process will be conducted as follows. First, to measure the instrument. Second, to prepare data for analysis. Third, to test the quality of data. Forth, hypotheses testing through multiple regressions.

\section{8- Data Analysis}

In the next part sample profiling, descriptive Statistics, statistical characteristics of the scale, and hypotheses testing will be discussed. 


\section{8-1 Profiling the Sample of the Study}

This part provides profiling of the study sample and the descriptive statistics of the variables (social media use, perceived value, brand trust, e-WOM, brand image and brand equity).

Table 2: Sample profiling

\begin{tabular}{|c|c|c|c|}
\hline & \multirow{3}{*}{$\begin{array}{c}\text { Frequency } \\
175 \\
\end{array}$} & \multirow{3}{*}{$\begin{array}{c}\text { Percentage } 100 \% \\
44.9\end{array}$} \\
\hline & & & \\
\hline \multirow{3}{*}{ Gender } & Male & & \\
\hline & Female & 215 & 55.1 \\
\hline & Sum & 390 & 100 \\
\hline \multirow{8}{*}{ Age } & 16-21 years & 4 & 1 \\
\hline & $22-30$ years & 10 & 2.5 \\
\hline & $31-40$ years & 153 & 39.2 \\
\hline & 41-50 years & 135 & 34.6 \\
\hline & $51-60$ & 27 & 7 \\
\hline & $60-70$ & 17 & 4.4 \\
\hline & More than 70 & 44 & 11.3 \\
\hline & Sum & 390 & 100 \\
\hline \multirow{5}{*}{ Marital Status } & & 196 & $50-2$ \\
\hline & Married & 131 & 33.6 \\
\hline & Divorced & 32 & 8.3 \\
\hline & Widowed & 31 & 7.9 \\
\hline & Sum & 390 & 100 \\
\hline \multirow{8}{*}{ Education } & Primary & 60 & 15.4 \\
\hline & Middle & 19 & 4.9 \\
\hline & High school & 50 & 12.8 \\
\hline & Bachelor & 150 & 38.5 \\
\hline & Diploma & 28 & 7.2 \\
\hline & MBA & 27 & 6.9 \\
\hline & PhD & 56 & 14.3 \\
\hline & Sum & 390 & 100 \\
\hline \multirow{8}{*}{ Income level } & Less than 1000 & 43 & 11.1 \\
\hline & $1000-2500$ & 106 & 27.2 \\
\hline & $2500-5000$ & 187 & 48 \\
\hline & $5000-10000$ & 32 & 8.2 \\
\hline & $10000-15000$ & 12 & 3 \\
\hline & $15000-20000$ & 8 & 2 \\
\hline & More than 20000 & 2 & 0.5 \\
\hline & Sum & 390 & 100 \\
\hline
\end{tabular}

Table (2) reveals respondents' aspects such as gender, age, marital status, education and income level. It was noted from the results that the 390 respondents were distributed between females $55.1 \%$, and $44.9 \%$ males. $2.5 \%$ of the respondents ages range between 22 and 30 years old, 
$50.2 \%$ of the them are single, $11.1 \%$ earn an income less than 1000 Egyptian Pounds and 38.5\% hold Bachelor certificate.

\section{8-2 Descriptive Statistics}

This section will provide the descriptive statistics for the six variables used in the conceptual framework (brand trust, perceived social media, brand image, e-WOM, perceived value, and brand equity). The researcher computed the means and standard deviations for all the questionnaire items.

Table 3: Descriptive statistics

\begin{tabular}{|c|c|c|c|}
\hline Items & $\mathbf{N}$ & Mean & $\begin{array}{c}\text { Std. } \\
\text { Deviation }\end{array}$ \\
\hline BT1 I trust this brand of the bank & 390 & 3.67 & 2.175 \\
\hline BT2 I rely on this brand of the bank & 390 & 3.87 & 1.911 \\
\hline BT3 This is an honest brand of the bank & 390 & 3.95 & 1.901 \\
\hline BT4 This brand of the bank is safe & 390 & 3.79 & 2.012 \\
\hline $\begin{array}{l}\text { SM1 I find interesting contents shown in social media } \\
\text { about the brand I am considering to buy }\end{array}$ & 390 & 4.59 & 2.043 \\
\hline $\begin{array}{l}\text { SM2 It is easy to deliver my opinion about the brand I am } \\
\text { considering buying through social media }\end{array}$ & 390 & 4.33 & 2.062 \\
\hline $\begin{array}{l}\text { Sm3 Using social media to search for information about } \\
\text { the brand I am considering buying is very trendy }\end{array}$ & 390 & 4.54 & 1.967 \\
\hline $\begin{array}{l}\text { SM4 I would like to pass along information on brand, } \\
\text { product, or services from social media to my friends. }\end{array}$ & 390 & 4.29 & 1.867 \\
\hline BI1 This bank is a leader in the banking industry. & 390 & 4.04 & 1.842 \\
\hline BI2 I have an impressive memory regarding this bank. & 390 & 4.51 & 1.975 \\
\hline BI3 This bank is customer-centered. & 390 & 4.17 & 1.913 \\
\hline $\begin{array}{ll}\text { e-WOM1 I will post positive opinions about this bank on } \\
\text { social media. }\end{array}$ & 390 & 3.91 & 2.020 \\
\hline e-WOM2 I will recommend this bank using social media. & 390 & 3.97 & 1.947 \\
\hline $\begin{array}{l}\text { e-WOM3 I will recommend this bank to my social media } \\
\text { friends. }\end{array}$ & 390 & 4.22 & 1.819 \\
\hline PV1 The bank service fees are fair and reasonable. & 390 & 3.93 & 2.055 \\
\hline $\begin{array}{l}\text { PV2 This bank offers the best service for the bank charges } \\
\text { I had to pay. }\end{array}$ & 390 & 4.04 & 1.770 \\
\hline PV3 The bank provides high quality customer services. & 390 & 4.06 & 1.885 \\
\hline PV4 This bank creates positive atmosphere. & 390 & 4.06 & 1.963 \\
\hline PV6 When in this bank I feel relaxed. & 390 & 3.34 & 2.057 \\
\hline PV6 I feel safe keeping my money in this bank. & 390 & 3.69 & 2.037 \\
\hline PV7 I feel trust and confident in this bank. & 390 & 3.81 & 1.999 \\
\hline $\begin{array}{l}\text { BE1 I find my bank more attractive compared to other } \\
\text { banks }\end{array}$ & 390 & 3.41 & 2.059 \\
\hline BE2 I have great respect for my bank & 390 & 4.43 & 2.112 \\
\hline BE3 I have positive feelings towards my preferred bank & 390 & 4.13 & 2.129 \\
\hline
\end{tabular}




\begin{tabular}{|l|c|c|c|}
\hline \multicolumn{1}{|c|}{ Items } & N & Mean & $\begin{array}{c}\text { Std. } \\
\text { Deviation }\end{array}$ \\
\hline $\begin{array}{l}\text { BE4 Even though the other banks offer similar services I } \\
\text { transact with my bank because it is a logical choice for } \\
\text { me }\end{array}$ & 390 & 3.61 & 2.127 \\
\hline Valid N (listwise) & 300 & & \\
\hline
\end{tabular}

As shown in table (3), the standard deviation for all items range between (1.770 - 2.175) and this shows there is no significant difference between values and average. The mean ranges between (3.61-4.59) and the least mean was for the fourth statement in brand equity "Even though the other banks offer similar services I transact with my bank because it is a logical choice for me". While, the highest was for the perceived social media use- the first statement- which is ". I find interesting contents shown in social media about the brand I am considering to buy".

\section{8-3 Statistical Characteristics of the Scale}

In the next part, validity and reliability tests will be presented to evaluate the instrument used in data gathering.

\section{8-3-1 Reliability and Validity}

This study uses Cronbach's Alpha Coefficient to ensure the reliability of the study measurements. Cronbach's Alpha Coefficient for all the study variables was measured to test the internal consistency of the measurement items for each variable. Cronbach alpha examines whether all the measurement items measure the same construct, by concentrating on the links between the construct measurement items (Tavakol \& Dennick, 2011). Knowing that 0.7 value and above is considered as accepted Cronbach Alpha value (Nunnally, 1978). The items represent an acceptable level of internal consistency if the Cronbach's alpha value within 0.5 to 0.7 and a good level if the Cronbach's alpha value more than 0.7. While the accepted threshold of Cronbach's Alpha Coefficient is between $0.5-0.7$, and 0.7 or greater is considered as a good level (Nunnally, 1978). Cronbach's Alpha Coefficient for all the study variables will be indicated in table (4) as follow: 
Table 4: Cronbach's Alpha Coefficient

\begin{tabular}{|l|c|c|}
\hline \multicolumn{1}{|c|}{ Research variables } & Cronbach's Alpha & Number of Items \\
\hline Brand Equity & 0.788 & 4 \\
\hline Perceived Value & 0.765 & 7 \\
\hline Brand Trust & 0.682 & 4 \\
\hline Social Media used & 0.526 & 4 \\
\hline Brand Image & 0.569 & 3 \\
\hline e-WOM & 0.580 & 3 \\
\hline
\end{tabular}

Table (4) revealed that Cronbach's Alpha Coefficient value fall between 0.526 for social media used and 0.788 for brand equity. This means that all research variables have the acceptable level of internal consistency.

This study depends on using both convergent and discriminant validities as a two fundamental aspects of construct validity. Convergent validity refers to how closely the new scale is related to other variables and other measures of the same construct. Not only should the construct correlate with related variables but it should not correlate with dissimilar, unrelated ones (de Vet et al., 2011; Streiner et al., 2015). The convergent validity of the study variables were measured through calculating the Pearson correlation coefficients among all variables as shown in table (5) whereby all the variables are significantly correlated with other, while the highest correlation exist between brand trust and perceived value $(\mathrm{r}=0.368)$ and the lowest correlation exists between brand trust and social media ( $\mathrm{r}=0.050)$, while the Correlations between variables did not exceed 0.8 , thus no serious multi-collinearity problem exists.

Despite significant and good reliability coefficient, it does not guarantee an accurately measured construct (Hair et al., 2010). Thus, a validity test is needed to carry out. This test introduces a deep satisfactory level of the measurement quality used. Hence in order to test the quality of measurements, this research will compare between the Cronbach alpha value for each variable with its correlation coefficients with the other study variables (Bagozzi et al., 1991). 
Table 5: Comparison between Correlation of Variables and Cronbach's alpha

\begin{tabular}{|l|c|c|c|c|c|c|c|}
\hline \multicolumn{1}{|c|}{ Variables } & $\begin{array}{c}\text { Perceived } \\
\text { Value }\end{array}$ & $\begin{array}{c}\text { Brand } \\
\text { Trust }\end{array}$ & $\begin{array}{c}\text { Social } \\
\text { Media }\end{array}$ & $\begin{array}{c}\text { Brand } \\
\text { Image }\end{array}$ & $\begin{array}{c}\text { e- } \\
\text { WOM }\end{array}$ & $\begin{array}{c}\text { Brand } \\
\text { Equity }\end{array}$ & $\begin{array}{c}\text { Cronbach's } \\
\text { alpha values }\end{array}$ \\
\hline Perceived Value & 1 & & &. &. & & 0.765 \\
\hline Brand Trust & $.368^{* *}$ & 1 & & & & & 0.682 \\
\hline Social Media & $.316^{* *}$ & .050 & 1 & & & & 0.526 \\
\hline Brand Image & $.329^{* *}$ & $.344^{* *}$ & $.302^{* *}$ & 1 & & & 0.569 \\
\hline e-WOM & $.294^{* *}$ & $.121^{*}$ & $.363^{* *}$ & $.163^{* *}$ & 1 & & 0.580 \\
\hline Brand Equity & $332^{* *}$ & $.366^{* *}$ & $.168^{* *}$ & $.343^{* *}$ & $.147^{* *}$ & 1 & 0.788 \\
\hline
\end{tabular}

$* *$ : statistical significant level at $1 \%$

*: statistical significant level at 5\%

Table (5) shows that the all the Cronbach's Alpha value for the study variables are greater than their correlation coefficients with the other variables. Hence the internal correlation between each variable construct are higher than the correlation between one study variable and another, which reveals that the variables used had discriminant validity. This study also applied exploratory factor analysis to identify the underlying relationships between measured variables, in which an accepted result for KMO was revealed (KMO=0.797 > 0.5) (Hair et al., 1998), and a significant Bartlett indicator with a Approx. chi square 2656.669 (Sig $=0.000$ ) was obtained as shown in following table (6). Based on the previous results the correlations among variables in each construct was appropriate.

Table 6: KMO and Bartlett's test results

\begin{tabular}{|l|c|c|}
\hline \multicolumn{2}{|l|}{ Kaiser-Meyer-Olkin Measure of Sampling Adequacy. } & .797 \\
\hline \multirow{3}{*}{ Bartlett's Test of Sphericity } & Approx. Chi-Square & 2656.669 \\
\cline { 2 - 3 } & $\mathrm{df}$ & 300 \\
\cline { 2 - 3 } & Sig. & .000 \\
\hline
\end{tabular}

The sampling is adequate if the value of KMO test is greater than 0.5 (Field, 2000; Kaiser, 1974). The Kaiser Meyer-Olkin value is 0.797 as shown in table (6). Which is exceeding the recommended minimum value of 0.5 (Kaiser, 1970, 1974). In SPSS the strength of correlation can be measured by a Bartlett Test of Sphericity. The Bartlett's Test of Sphericity for marketing is statistical significance (see table), supporting the factorability of the correlation matrix. The factor scores are correlated; Variance inflation factor (VIF) and tolerance level were used in this study to depict collinearity among the study independent variables, in which all the VIF values must be less than 4 . The VIF 
translates the tolerance value, which directly expresses the degree of multicollinearity, into an impact on the estimation process. As the standard error is increased, it makes the confidence intervals around the estimated coefficients larger, thus making it harder to demonstrate that the coefficient is significantly different from zero. (Hair et al., 2010). As shown in table (7) there are no serious multi-collinearity problem between the study independent variables.

Table 7: VIF Coefficientsa

\begin{tabular}{|c|c|c|}
\hline \multicolumn{2}{|c|}{ Model } & Collinearity Statistics \\
\cline { 2 - 2 } \multicolumn{2}{|c|}{} & VIF \\
\cline { 2 - 2 } 1 & (Constant) & \\
\cline { 2 - 2 } & BT & 1.149 \\
\cline { 2 - 3 } & SM & 1.248 \\
& BI & 1.250 \\
\cline { 2 - 3 } & EWOM & 1.167 \\
\hline
\end{tabular}

\section{8-4 Hypotheses Testing}

This study performed multiple regression analysis to illustrate the relationship between the study independent variables and dependents variables on two stages which are multiple regression one and multiple regression two which will be clarified as follow: First, multiple regression one, was performed to examine the relationships between the following independent variables: (1) Social media, (2) perceived value, (3) brand trust, and (4) e-WOM and the dependent variable (brand image). Second, multiple regression two, which examines the relationships between the following independent variables (1) Social media, (2) brand trust, (3) e-WOM and (4) (brand image) and the dependent variable (brand equity). In other words, multiple regression analysis was used to test the study hypotheses, along with measuring the significance of the study models. Based on the aforementioned discussion, hypotheses testing will be performed in the coming section on three stages. First testing H1, H2, H3, and H4. Second testing H5, H6, H7and H8. Finally testing the mediating effect of brand image which includes testing $\mathrm{H} 9, \mathrm{H} 10$ and $\mathrm{H} 11$. 


\section{8-4-1- Testing H1, H2, H3, and H4}

Multiple regression is used to test the relationship among social media, perceived value, brand trust, and e-WOM and the dependent variable (brand image)

Table 8: First Regression Analysis Results

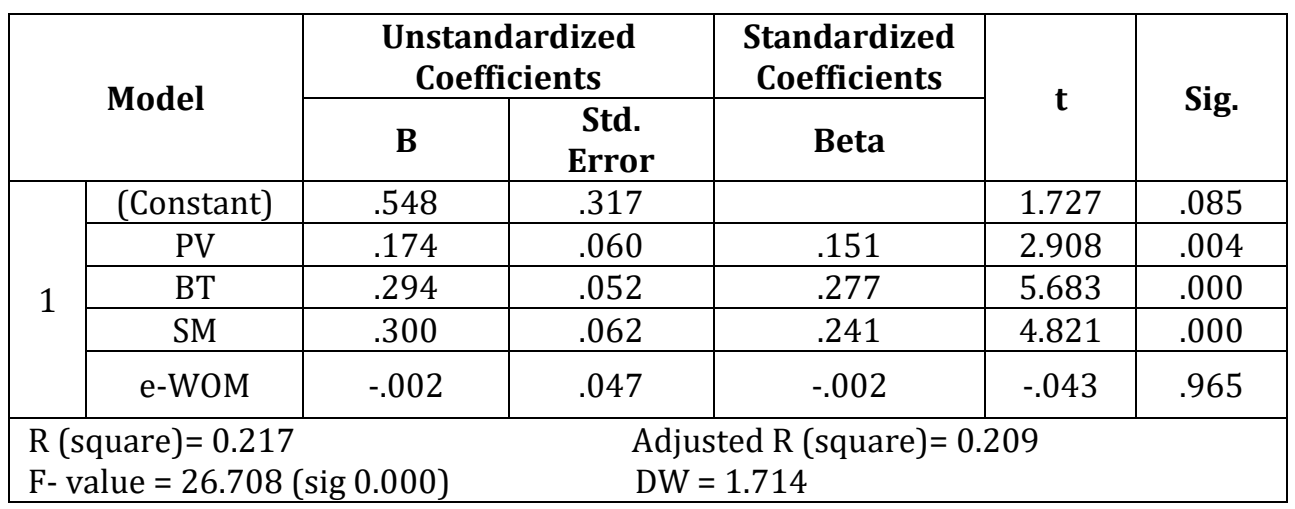

Dependent Variable: Brand Image

As shown in table (8), R Square $=0.217$ and Adjusted R Square $=0.209$, which reveals that $20.9 \%$ of the variation in brand image is due to the change in (1) Social media, (2) perceived value, (3) brand trust and (4) e-WOM. In other words, $79.1 \%$ of the variation in brand image is due to other factors than those under this study consideration. While ANOVA test reveals that the regression model has significant explanatory power (F statistic 26.708; $\mathrm{p}<0.01$ ). Also, the regression analysis table reveals the regression coefficients of each independent variable uniquely in the model to evaluate its relationship with brand image. In other words, the previous table allows testing the hypotheses $\mathrm{H} 1, \mathrm{H} 2, \mathrm{H} 3$ and $\mathrm{H} 4$ as follow: Testing H1: Results reveals that the first hypothesis in this study which stated that Social media use has a significant positive effect on brand image is supported $(\beta=0.300$ and $t=4.821$ with sig $=0.000<0.05)$ at significant level 5\%. Due to testing $\mathrm{H} 2$, which stated that perceived value has a significant positive effect on brand image is supported as shown in table $(8)$ where $(\beta=0.174$ and $t=2.908$ with sig $=0.004<0.05)$ at significant level $5 \%$. Regarding $\mathrm{H} 3$ which stated that Brand trust has a significant positive effect on brand image - as shown in table (7) - is also supported where $(\beta=0.294$ and $t=5.683$ with sig $=0.000<0.05)$ at significant level 5\%. As shown in table (8) H4 which stated that e-WOM 
has a significant influence on brand image is rejected where $(\beta=-0.002$ and $\mathrm{t}=-0.043$ with sig $=0.965<0.05$ ) at significant level $5 \%$.

\section{8-4-2 Testing H5, H6, $\mathrm{H7}$ and $\mathrm{H8}$}

Multiple regression analysis two is performed to test the effect of social media, brand trust, brand image, e-WOM and the depended variable brand image on brand equity.

Table 9: Second Regression Analysis Results

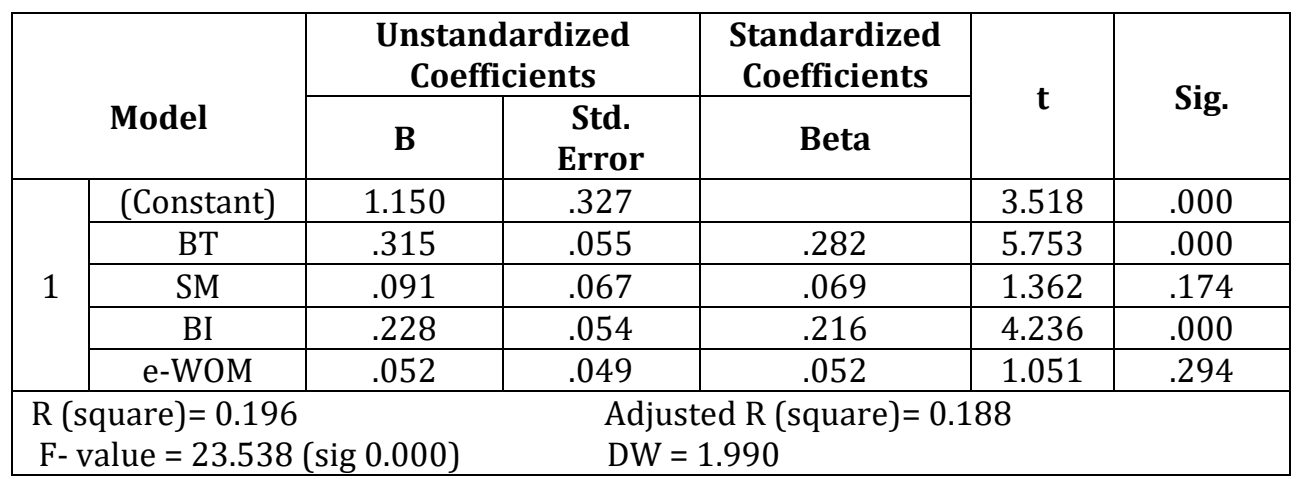

Dependent Variable: Brand Equity

Furthermore, based on table (9), the second regression analysis, $\mathrm{R}$ Square $=0.196$ and Adjusted R Square $=0.188$, which reveals that $18.8 \%$ of the variation in brand equity is due to the change in (1) Social media, (2) brand trust, (3) brand image and (4) e-WOM. In other words, $81.2 \%$ of the variation in brand equity is due to other factors than those under this study consideration. While ANOVA test reveals that the regression model has significant explanatory power (F statistic 23.538; $p<0.05$ ). Also, the regression analysis table reveals the regression coefficients of each independent variable uniquely in the model to evaluate its relationship with brand equity. In other words, the previous table allows testing the hypotheses (H5, H6, H7 and H8) as follow: The results reveal that the fifth hypothesis in this study which stated that social media use has a significant positive effect on brand equity, is rejected where $(\beta=0.091$ and $\mathrm{t}=1.362$ with sig $=0.174>0.05$ ) at significant level $5 \%$. Due to testing H6, the results revealed that the sixth hypothesis in this study which stated that brand trust has a significant influence on brand equity, is Supported $(\beta=0.315$ and $t=5.753$ with sig $=0.000<0.05)$ at significant level $5 \%$. Regarding H7, the results revealed that the seventh hypothesis in this study which stated that e-WOM has a significant influence on brand 
equity, is rejected $(\beta=0.052$ and $t=1.051$ with $\operatorname{sig}=0.294>0.05)$ at significant level $5 \%$. Finally, the results revealed that the eighth hypothesis in this study which stated that brand image has a significant influence on brand equity is supported where $(\beta=0.228$ and $t=4.236$ with sig $=0.000<0.05)$ at significant level $5 \%$.

\section{8-4-3 Examining the Mediation Role of Brand Image}

To examine the mediation role of a certain variable (mediator) on the relationship between the predictor (social media; brand trust; e-WOM) and the criterion (brand equity), both direct and indirect path must be examined. Whereby the direct path is the direct relationship between the predictor and criterion. Examining the indirect path requires examining two relationships as follows: first, the relationship between the predictor and the mediator. The second relationship between the mediator and the criterion. In the coming section, the researcher examined the mediation role of brand equity on the following three relationships: (1) H9 (between social media and brand equity), (2) H10 (between brand trust and brand equity), and (3) H11 (between e-WOM and brand equity). The researcher examines the mediation role of brand image, by applying the process procedure for SPSS. Whereby, the direct and indirect effects for the predictor on the criterion are examined (Montoya \& Hayes, 2017).

\section{8-4-3-1 Testing H9}

Table (10) summarizes the direct effect of social media on brand equity and indirect effect of the couples of variables through the mediator variable which is brand image.

Table 10: The mediating role of brand image on the relationship between social media use and brand equity

\begin{tabular}{|c|c|c|c|c|}
\hline \multicolumn{5}{|c|}{ Direct Effect } \\
\hline Effect & $\mathrm{t}$ & $\mathrm{p}$ & LLCI & ULCI \\
\hline 0.0926 & 1.4137 & 0.1583 & -0.0362 & 0.2214 \\
\hline \multicolumn{5}{|c|}{ Indirect effect } \\
\hline & Effect & & LLCI & ULCI \\
\hline & 0.1271 & & 0.0717 & 0.1891 \\
\hline \multicolumn{5}{|c|}{$F=26.8854(0.0000)$} \\
\hline
\end{tabular}

LLCI: (The lower limit confidence interval) ULCI: (The upper limit confidence interval) 
As shown in table (10) which examine the mediation role for brand image on the relationship between social medial use and brand equity, the results revealed a significant f-test $(f=26.8854, p=0.0000$. Moreover, an insignificant direct effect exists between social media and brand equity ( $\mathrm{t}=1.4137, \mathrm{p}=0.158)$. furthermore, the results show a significant indirect relationship through brand image since the interval between LLCI (The lower limit confidence interval) and ULCI (The upper limit confidence interval) did not include zero (0.0717; 0.1891). based on the aforementioned analysis BI fully mediated the relationship between SM and BE. Thus, H9 is supported.

\section{8-4-3-2 Testing H10}

Table (11) shows the direct effect of brand trust on brand equity and indirect effect of the two variables through the mediator variable which is brand image.

Table 11: The mediating role of brand image on the relationship between brand trust and brand equity

\begin{tabular}{|c|c|c|c|c|}
\hline \multicolumn{5}{|c|}{ Direct Effect } \\
\hline Effect & t & $\mathbf{p}$ & LLCI & ULCI \\
\hline 0.0926 & 5.7636 & 0.0000 & 0.2070 & 0.4213 \\
\hline \multicolumn{5}{|c|}{ Indirect effect } \\
\hline \multicolumn{3}{|c|}{ Effect } & LLCI & ULCI \\
\hline \multicolumn{3}{|c|}{0.0945} & 0.0489 & 0.1446 \\
\hline \multicolumn{5}{|c|}{$F=44.5736(0.0000)$} \\
\hline
\end{tabular}

LLCI: (The lower limit confidence interval)

ULCI: (The upper limit confidence interval)

Based to table (11) which examine the mediation role for brand image on the relationship between brand trust and band equity, the results revealed a significant $\mathrm{f}-$ test $(\mathrm{F}=44.5736, \mathrm{p}=0.0000)$. Moreover, $\mathrm{a}$ significant direct effect exists between brand trust and brand equity $(\mathrm{t}=5.7636, \mathrm{p}=0.0000)$. Furthermore, the results show a significant indirect relationship through brand image since the interval between LLCI and ULCI did not include zero $(0.0489 ; 0.1446)$. Based on the aforementioned analysis BI partially mediate the relationship between BT and BE. Thus, H10 is supported. 


\section{8-4-3-3 Testing H11}

Table (12) summarizes the direct effect of e-WOM on brand equity and indirect effect between the couples of variables through the mediator variable brand image

Table 12: The mediating role of brand image on the relationship between e-WOM and brand equity

\begin{tabular}{|c|c|c|c|c|}
\hline \multicolumn{5}{|c|}{ Direct Effect } \\
\hline Effect & $t$ & $\mathrm{p}$ & LLCI & ULCI \\
\hline 0.0928 & 1.8330 & 0.0540 & -0.0016 & 0.1872 \\
\hline \multicolumn{5}{|c|}{ Indirect effect } \\
\hline \multicolumn{3}{|c|}{ Effect } & LLCI & ULCI \\
\hline & & & 0.0141 & 0.0962 \\
\hline \multicolumn{5}{|c|}{$F=27.8701(0.0000$} \\
\hline
\end{tabular}

LLCI: (The lower limit confidence interval)

ULCI: (The upper limit confidence interval)

Based on table (12) which examines the mediation role of brand image on the relationship between e-WOM and band equity, the results revealed a significant $\mathrm{f}-$ test $(\mathrm{F}=27.8701, \mathrm{p}=0.0000)$. Moreover, an insignificant direct effect exists between e-WOM and brand equity $(\mathrm{t}=1.8330, \mathrm{p}=0.0540)$. furthermore, the results show a significant indirect relationship through brand image since the interval between LLCI and ULCI did not include zero $(0.0141 ; 0.0962)$. based on the aforementioned analysis BI partially fully mediate the relationship between e-WOM and BE. Thus, H11 is supported. Table (13) summarizes the main findings of hypotheses testing as follows:

Table 13: Hypothesis Testing Results

\begin{tabular}{|c|l|c|}
\hline Hypotheses & \multicolumn{1}{|c|}{ Hypotheses } & Results \\
\hline H $_{1}$ & $\begin{array}{l}\text { Social media use has a significant positive effect on } \\
\text { brand image in the Egyptian banking sector. }\end{array}$ & Supported \\
\hline H 2 & $\begin{array}{l}\text { Perceived value has a significant positive effect on } \\
\text { brand image in the Egyptian banking sector. }\end{array}$ & Supported \\
\hline H 3 & $\begin{array}{l}\text { Brand trust has a significant positive effect on } \\
\text { brand image in the Egyptian banking sector. }\end{array}$ & Supported \\
\hline H4 & $\begin{array}{l}\text { e-WOM has a significant influence on brand image } \\
\text { in the Egyptian banking sector. }\end{array}$ & Rejected \\
\hline H5 & $\begin{array}{l}\text { Social media use has a significant positive effect on } \\
\text { brand equity in the Egyptian banking sector. }\end{array}$ & Rejected \\
\hline H6 & $\begin{array}{l}\text { Brand trust has a significant influence on brand } \\
\text { equity in the Egyptian banking sector. }\end{array}$ & Supported \\
\hline
\end{tabular}




\begin{tabular}{|c|l|c|}
\hline H7 & $\begin{array}{l}\text { e-WOM has a significant influence on brand equity } \\
\text { in the Egyptian banking sector. }\end{array}$ & Rejected \\
\hline H8 & $\begin{array}{l}\text { Brand image has a significant influence on brand } \\
\text { equity in the Egyptian banking sector. }\end{array}$ & Supported \\
\hline H9 & $\begin{array}{l}\text { Brand image mediates the relationship between } \\
\text { social media use and brand equity in the Egyptian } \\
\text { banking sector. }\end{array}$ & Supported \\
\hline H10 & $\begin{array}{l}\text { Brand image mediates the relationship between } \\
\text { brand trust and brand equity in the Egyptian } \\
\text { banking sector. }\end{array}$ & Supported \\
\hline H11 & $\begin{array}{l}\text { Brand image mediates the relationship between e- } \\
\text { WOM and brand equity in the Egyptian banking } \\
\text { sector. }\end{array}$ & Supported \\
\hline
\end{tabular}

\section{9- Discussion}

This study investigates factors affecting brand equity in the Egyptian banking sector. These factors include social media use, perceived value, brand trust, e-WOM of mouth, and brand image. According to the findings discussed social media use, perceived value, and brand trust has a significant positive effect on brand image. and the three independent factors with e-WOM explain 0.209 of a variation in the dependent variable the brand image. The impact of each factor on the brand image is varied. The first finding showed that social media use has a significant positive effect on brand image is supported. This is maybe due to the vital roles played by social media on customer's beliefs held about a particular brand. The improved usage of social media has altered the way people interact and communicate, also it eased the way for brands to utilize these social media networks to promote and advertise their products. Literature review supported this result (Pozin, 2014, Graves (2016), Grubor \& Jaksa, (2018). The results revealed that perceived value has a significant positive effect on brand image. This is explained as when customers experience deep trust for a certain brand, the brand is most likely to be imprinted in their mind, hence the more perceived value it is perceived to be the more positive brand image is gained by consumers. This result is supported by literature (Nowak \& Washbrun, 2002; Yoo \& Donthu, 2002). The study findings stated that brand trust has a significant positive effect on brand image. This result may explain the importance of building customer trust in the banking sector which plays a vital role in forming a positive image. where the results are with support with the literature findings which showed a significantly positive relationship with brand trust and higher 
brand image (Alhaddad, 2015). Thus, higher trust and image will attract more consumers. The results also indicated that the fourth hypothesis stated that e-WOM has a significant influence on brand image is not supported. This result may be due to the nature of the brand image in the financial banking sector which is entirely different from the other services sectors. Services in the financial sector are highly influenced by customer trust and perceived value and e-WOM didn't play a significant role in building the brand image. This result disagreed with the marketing literature (Chevalier \& Mayzlin, 2006; Jalilvand, 2012).

The study revealed that social media use didn't significantly affect brand equity. From the researcher's point of view, brand equity items are not important in social media and are not important for the company to achieve a high return on marketing investment in their social networks. The reason which interprets this result may be the sample units have a concern to reduce the perceived financial risks, so they prefer to conduct their transactions with governmental Egyptian banks instead of depending on social media as a way to build brand equity. This result disagrees with the literature review (Hilal; 2019, Kumar et al., 2016). The results indicated also that brand trust affected positively brand equity. This resultin the researcher's perspective- means that brand trust plays a vital role in building brand equity as a relational market asset in the Egyptian banking sector. This result is confirmed by a literature review in marketing (Garbarino \& Johnson, 1999; Krishnan, 1996; Davcik, 2013. Raut et al., (2019). The study also rejected the hypothesis which stated that e-WOM has a significant influence on brand equity. This may be explained that The effect of e-WOM is expected to be greater than traditional word-of-mouth because of its convenience, scope, source, and speed of interactions in building brand equity furthermore, The Internet can amplify differences among banks and by providing more information it can reduce consumers' uncertainty, leading to a positive impact on brand equity. On the research level, the literature review supports this result like Yasin \& Zahari (2011) \& Murtiasih et al., (2013). The study also revealed that brand image is positively affected brand equity. The results imply that positive evaluations about a bank or a brand are playing a vital role, and are likely to help consumers positively assess a brand, and enhance their attachment towards it. Therefore, developing a positive brand image strengthens 
brand equity. This result is supported by a literature review (Ansari \& Hachem, 2017; Jaiprakash, 2008).

In this research, the mediating role of brand image on the relationship between social media use, brand trust, and e-WOM is analyzed. The results revealed that although the brand image is fully mediating the relationship between social media use and brand equity, it is partially mediating the relationship between brand trust and brand equity and also partially mediates the relationship between e-WOM and brand equity. This means that social media use does not affect brand equity without the brand image. This result may be explained due to the majority of sample units was considered as an Egyptian youngster, whereby they deeply depend on the brand image as a way to associate and to understand the effect of social media use on brand equity. On the literature review level, this result is supported by the research (Seo \& Park, 2018; Ansari \& Hachem, 2017).

The results indicated also that brand image partially mediates the relationship between brand trust and brand equity. This result is interpreted through that brand equity is enhanced by both brand trust and brand image and this is reinforced by the special nature of financial services to the respondents which entails a sufficient level of consumer trust and positive brand image to support brand equity. On the academic, this result is confirmed (Alhaddad, 2015; Ansary \& Hashim, 2017).

The results revealed also that brand image partially mediates the relationship between e-WOM and brand equity. This means that banks should create positive e-WOM which in turn will influence and reinforce brand equity positively. The result may be explained due to the majority of sample units are fallen in the category between 22 to 40 years old ( 0.584 of the sample size). This category is intensively depending on social media to build their image, so unlike most literature that suggests causality effects, the present study considers that brand image is partially mediating the relationship between e-WOM and brand equity although e-WOM didn't have significant effect on brand equity (Jansen et al., 2009; Severi et al., 2014). 


\section{0- Research Implications}

The results revealed by this research contribute to the branding literature in several ways. First, this study clarified the effect of social media use, perceived value, brand trust, e-WOM, and brand image on brand equity. Unlike the prior literature (Gürhan-Canli et al., 2016; Keller, 2016). which proved a significant and a causal relationship between social media use and brand equity, the results indicated that social media use has no significant effect on brand equity. Unlike the branding literature (Bambauer \& Mangold 2011; Yasin \& Zahari 2011; Murtiasih et al., 2013) affirmed the significant and causal effect of e-WOM on brand equity, this study stated that e-WOM has no significant effect on brand equity. Thus, this research provides empirical support to the impact of social media use and e-WOM on brand equity. Second, by analyzing the mediating role of the brand image between social media use, perceived value, e-WOM, and brand equity, this study focused on the vital role played by the brand image in building brand equity. Also, the interplay between social media use, perceived value, e-WOM, brand image, and brand equity is delineated which provides insights for future research. The results provide empirical evidence that the conceptual framework can be modified or extended to enrich the deep understanding of brand equity. Third, the results obtained by this study enrich brand equity literature through the integration of the literature on the resource-based view of the firm and the stakeholder's theory. The resource-based view is helping to better understand brand equity as a relational market-based asset through considering brand trust as a vital construct to build brand equity. This resource with other resources such as perceived value, social media use, and e-WOM should be integrated to enhance brand equity which is considered as a resource-based competitive advantage.

Stakeholders' view of the firm stated that a firm is relying on a network of relationships in which it becomes obliged to the members of this network. So, building brand equity requires the firms to consider the relationship with members of the value chain. This entails future research to includes more relational variables such as employees and suppliers. 


\section{1-Managerial Implications}

This study is providing several practical implications. First, the interplay between social media use, perceived value, e-WOM, and brand image requires that managers in banking sectors concentrate on developing and creating perceived value, customer brand trust, and positive brand image to enhance brand equity. However, although the synergistic effect of these variables together on brand equity, brand trust, and brand image are the stronger variables affecting brand equity, this is implying that creating and enhancing customer trust and brand image are relatively important to support brand equity. Second, although social media use has no significant effect on brand equity, social media use significantly affects brand equity through brand image. Thus bank managers should effectively employ social media use to enhance bank brand image which in turn affects bank brand equity. Third, bank managers should be aware that building a positive brand image will improve their competitive position. To build a positive brand image manager should obtain customers' insights through social networking sites to convey positive signals about the perceived value, brand trust, e-WOM which in turn strengthening brand equity. Bank managers are strongly recommended to use social networking sites to conducting promotional campaigns to improve their brand image. Managers also are recommended to investigate social media to collect customer opinions, reviews, suggestions, and complaints to improve the image of their bank and to better understand customer behaviors. Managers can employ e-WOM as a credible channel to communicate the competitive advantages to their customer which in turn improve consumer trust and brand image.

In summary, this study advances the knowledge to help managers in the banking sector to improve brand equity by integrating social media use, perceived value, brand trust, e-WOM, and brand image. The study highlighting the vital role of brand image as a mediator variable in enhancing brand equity. The results revealed that social media use and eWOM as a construct have no significant effect on brand equity. Mangers are recommended to use both couples of variables to improve brand image. The empirical evidence revealed that brand image is a vital variable affecting brand equity. 


\section{2- Recommendations}

Based on the current research findings, this study proposes several recommendations for managers and decision makers to enhance brand image and equity in banking sector. These recommendations are briefly summarized as follow:

- Referring to the first result, which indicated that social media use has a significant positive influence on brand image, this research recommends the customer service department in banking sectors to devote much more attention to interactions and the news with bank`s customer. This attention can be achieved through watching and following social media platforms such as Facebook and Twitter to enhance and improve the brand image of the bank.

- The second result revealed that perceived value had a significant positive effect on brand image. Based on this result, the researcher recommended the managers to create, communicate, distribute and maximize value perceived by the customers. This value maximization will enhance brand image of the bank, value maximization might be achieved through introducing new innovative services, reducing queuing lines, and improving the physical dimensions of the services introduced, such as making the ATM machines available and high convenience for banks` customers.

- The research findings revealed also that brand trust perceived by the customers is significantly affect brand image. Based on this result, the study recommended banks' managers to work on enhancing brand trust. Raising of level of customers perceived trust will be achieved through reducing customers' perceived risks. This can be achieved through reviewing security system, through securing online customers` transactions.

- The fourth results indicated that e-WOM doesn't influence banks ' brand image, thus the researcher recommends managers to focus on other factors to build strong brand image, such as; social media use, perceived value, and trust. Surveying customers' opinions to measure the level of customer satisfaction and loyalty periodically might help in enhancing the brand image of the bank. 
- The results revealed that social media use didn't has a significant positive effect on brand equity. Thus, the researcher highly recommends mangers to concentrate on other variables affecting brand equity in banking sector, such as; brand trust and brand image. Creating and distributing competitive customer perceived value may enhance the brand equity of the bank.

- The current study findings pointed out that brand trust has a significant influence on brand equity. Thus, the researcher recommends the banks' mangers to enhance brand trust though keeping their promises in developing innovative new services and maintain strong relationships with their customers. Developing and maintaining stronger relationships with customers can be performed through introducing frequency programs and create motives to inspire customers to participate in value co-creation activities.

- The findings indicated that e-WOM didn't influence brand equity. Hence the researcher recommends the managers to concentrate on building brand awareness, through public relation campaign rather than e-WOM.

- The results showed that brand image has a significant influence on brand equity. Based on this result, the researcher recommends that managers in banking sector to focus on the vital role played by brand image in building brand equity. This can be achieved by creating events and adopting corporate social responsibility programs, which strengthen the banks' image. Activating the vital role of public relation might enhance the image of the bank which relatedly improve the bank brand equity.

\section{3- Limitations and Ideas for Future Research}

Like any other research, this research has six limitations which can be considered as an important suggestion for future research. First, Although the main dependent variable investigated by the study is brand equity entails a long period to be effectively observed, evaluated, and measured, this study relied on a cross-sectional sampling technique which is a judgmental or purposive sample. Therefore, the time dimension may undermine the value of the results of this study especially with the current accelerated environmental changes so the current research findings 
should be used with caution. Thus, a longitudinal sample is recommended to be used in future research.

Second, this study considered five variables to analyze brand equity but many other important variables should be taken place to better understand the phenomenon such as customer satisfaction, loyalty, perceived value, self-image, and perceived risks. Therefore, this study recommends extending the current conceptual framework to include these variables to build a more integrated framework in understanding brand equity.

Third, although the concept of brand equity is a vital concept for the success of the companies working across different sectors such as automobile, electronic, food, insurance, and education, this study analyzed the concept in the banking sector only so it is recommended to investigate brand equity in other sectors. Forth Although different countries have different cultures, attitudes, and behaviors, this study is conducted in Alexandria in Egypt, so the results should be used with caution and it is recommended to duplicate the framework in other cultures and conducting comparative studies to conclude the behavior differences across the different countries to gain more insights for international and global companies.

Fifth, brand image is used in the current study as a mediator between the independent variables and brand equity. Future research could address other mediators such as brand personality, customer perceived value, and brand trust. Sixth, this study concentrates only on the antecedents or the inputs of brand equity without investigating the potential consequences, findings, or the outputs which expected to be achieved through enhancing brand equity such as key performance indicators. Future research is recommended to investigate both antecedents and consequences of developing and improving brand equity. 


\section{References}

Aaker, D.A. (1991). Managing brand equity. The Free Press: New York, NY.

Aaker, D.A. (1992). The Value of Brand Equity. Journal of Business Strategy, 13(4), 27-32.

Alam, M. S. and Khan, B. M. (2015). Impact of social media on Brand equity: A literature analysis. AIMA Journal of Management \& Research, 9(4), 1-12.

Alhaddad, A. (2015). Perceived quality, brand image and brand trust as determinants of brand loyalty. Journal of Research in Business and Management, 3(4), 1-8.

Algharabat, R.; Rana, N. P.; Alalwan, A. A.; Baabdullah, A., \& Gupta, A. (2020). Investigating the antecedents of customer brand engagement and consumer-based brand equity in social media. Journal of Retailing and Consumer Services, 53, 1-13.

Andreassen, W. T. and Lindestad, B. (1998). Customer loyalty and complex services. International Journal of Service Industry Management, 9(1), 7-23.

Ansary, A. and Hashim, N. M. (2018). Brand image and equity: The mediating role of brand equity drivers and moderating effects of product type and word of mouth. Review of Managerial Science, 12(4), 969-1002.

Ashraf, A. R.; Tek, N. T.; Anwar, A.; Lapa, L., \& Venkatesh, V. (2021). Perceived values and motivations influencing m-commerce use: A nine-country comparative study. International Journal of Information Management, 59.

Atilgan, E.; Akinci, S.; Aksoy, S. and Kaynak, E. (2009). Customer-based brand equity for global brands: A multinational approach. Journal of Euro marketing, 18(2), 115-132.

Baalbaki, S. S. (2012). Consumer Perception of Brand Equity Measurement: A New Scale, page 16, Dissertation of doctor of philosophy, University of North Texas. 
Bagozzi, R. P.; Yi, Y. and Phillips, L. W. (1991). Assessing construct validity in organizational research. Administrative science quarterly, 36(3), 421-458.

Bambauer-Sachse, S. and Mangold, S. (2011). Brand equity dilution through negative online word-of-mouth communication. Journal of retailing and consumer services, 18(1), 38-45.

Barich, H. and Kotler, P. (1991). A framework for marketing image management. Sloan Management Review, 32(2), 94-104.

Boyd, D. M., \& Ellison, N. B. (2007). Social network sites: Definition, history, and scholarship. Journal of computer-mediated Communication, 13(1), 210-230.

Bryman, A. and Cramer, D. (2002). Quantitative data analysis with SPSS release 8 for Windows: a guide for social scientists. Routledge.

Caceres, R. C. and Paparoidamis, N. G. (2007). Service quality, relationship satisfaction, trust, commitment and business-tobusiness loyalty. European journal of marketing, 41(7/8), 836867.

Castillo, A.; Benitez, J.; Llorens, J., \& Luo, X. R. (2021). Social media-driven customer engagement and movie performance: Theory and empirical evidence. Decision Support Systems, 145.

Chattopadhyay, T.; Dutta, R. N. and Sivani, S. (2010). Media mix elements affecting brand equity: A study of the Indian passenger car market. IIMB Management Review, 22(4), 173-185.

Chatzipanagiotou, K.; Veloutsou, C. and Christodoulides, G. (2016). Decoding the complexity of the consumer-based brand equity process. Journal of Business Research, 69(11), 5479-5486.

Chaudhuri, A. and Holbrook, M. B. (2001). The chain of effects from brand trust and brand affect to brand performance: the role of brand loyalty. Journal of marketing, 65(2), 81-93.

Chevalier, J. A. and Mayzlin, D. (2006). The effect of word of mouth on sales: Online book reviews. Journal of Marketing Research, 43(3), 345-354. 
Christodoulides, G.; Cadogan, J.W. and Veloutsou, C. (2015). Consumerbased brand equity measurement: lessons learned from an international study. International Marketing Review, 32(3/4), 307-328.

Cretu, A. E. and Brodie, R. J. (2007). The influence of brand image and company reputation where manufacturers market to small firms: A customer value perspective. Industrial marketing management, 36(2), 230-240.

Davcik, N. S. (2013). An empirical investigation of brand equity: drivers and their consequences. British Food Journal, 115(9), 13421360 .

De Chernatony, L. and Segal-Horn, S. (2001). Building on services' characteristics to develop successful services brands. Journal of marketing management, 17(7-8), 645-669.

Dehdashti, Z.; Kenari, M. and Bakhshizadeh, A. (2012). The impact of social identity of brand on brand loyalty development. Management Science Letters, 2(4), 1425-1434.

Delgado, E. and Munuera, J. (2005). Does brand trust matter to brand equity?. Journal of Product and Brand Management, 14(3), 18796.

Deloitte. (2013). The Logistics Industry in Turkey. Investment Support and Promotion Agency of Turkey, Turkey. Retrieved from http://www.invest.gov.tr/enUS/infocenter/publications/Docu ment s/TRANSPORTATION-LOGISTICSINDUSTRY.pdf

Edwards, K. (1990). The interplay of affect and cognition in attitude formation and change. Journal of personality and social psychology, 59(2), 202-216.

Ehsani, Z. and Hashim, N. (2015). Effect of customer perceived value on customer relationship management performance. International Journal of Science, Commerce and Humanities, 3(1), 139-146. 
Elsharnouby, T. and Parsons, E. (2010). A broader concept of relationships: Identifying new forms of consumer-provider interactions in Egyptian financial services. Journal of Marketing Management, 26(13-14), 1367-1388.

Esch, F.R.; Langner, T.; Schmitt, B. H. and Geus, P. (2006). Are brands forever? How brand knowledge and relationships affect current and future purchases. Journal of Product and Brand Management; 15(2), 98-105.

Ferguson, R. and Hlavinka, K. (2007). The COLLOQUY loyalty marketing census: sizing up the US loyalty marketing industry. Journal of Consumer Marketing, 24(5), 3131-321.

Field, A. (2000). Discovering Statistics using SPSS for Windows. London, Thousand Oaks - New Delhi: Sage publications.

Freeman, S.; Deligonul, S. and Cavusgil, T. (2013). Strategic re-structuring by born-global using outward and inward-oriented activity. International Marketing Review, 30(2), 156-182.

Friedman, A.L. and Miles, S. (2006). Stakeholders: Theory and Practice. Oxford University Press.

Fuentes-Blasco, M.; Moliner-Velázquez, B. and Gil-Saura, I. (2017). Analyzing heterogeneity on the value, satisfaction, word-ofmouth relationship in retailing. Management Decision, 55(7), 1558-1577.

Garbarino, E. and Johnson, M. S. (1999). The different roles of satisfaction, trust, and commitment in customer relationships. Journal of marketing, 63(2), 70-87.

Gheorghe, I. R. and Liao, M. N. (2012). Investigating Romanian healthcare consumer behaviour in online communities: Qualitative research on negative e-WOM. Procedia-Social and Behavioral Sciences, 62, 268-274.

Graves, M. F. (2016). The vocabulary book: Learning and instruction. Teachers College Press. 
Gronroos, C. (1990). Relationship approach to marketing in service contexts: The marketing and organizational behavior interface. Journal of business research, 20(1), 3-11.

Grubor, A., \& Jakša, O. (2018). Internet marketing as a business necessity. Interdisciplinary Description of Complex Systems: INDECS, 16(2), 265-274.

Gürhan-Canli, Z.; Hayran, C. and Sarial-Abi, G. (2016). Customer-based brand equity in a technologically fast-paced, connected, and constrained environment. AMS review, 6(1), 23-32.

Hadinata, Y. (2021). The effect of Perceived Quality and Brand Image on Brand Trust and Brand Loyalty Yamaha MIO in Surabaya.Journal of Recent Economy and Management, 18(1), 1-10.

Hair, J. F.; Black, W. C.; Balin, B. j. and Anderson, R. E. (2010). Multivariate data analysis: Maxwell Macmillan International Editions.

Hair, J. F.; Anderson, R. E.; Tatham, R. L. and Black, W.C. (1998). Multivariate Data Analysis, fifth ed. Prentice Hall, New Jersey.

Han, Sung, H. o.; Cheng-Hao Steve Chen and Timothy, J.; Lee (2021). The interaction between individual cultural values and the cognitive and social processes of global restaurant brand equity. International Journal of Hospitality Management. 94.

Hong, E.; Hartzell, S. A. and Greene, M. T. (2009). Fostering creativity in the classroom: Effects of teachers' epistemological beliefs, motivation, and goal orientation. The Journal of Creative Behavior, 43(3), 192-208.

Hasan, H.; Kiong, T. P. and Ainuddin, R. A. (2014). Effects of perceived value and trust on customer loyalty towards foreign banks in Sabah, Malaysia. Global Journal of Emerging Trends in e-Business, Marketing and Consumer Psychology, 1(2), 137-153.

Haythornthwaite, C. (2005). Social networks and Internet connectivity effects. Information, Community \& Society, 8(2), 125-147. 
Hilal, M. I. (2019). Impact of social media marketing efforts on Destination's brand equity: A study among International Tourists arriving to Sri Lanka. In 2019 3rd International Conference on Computing and Communications Technologies (ICCCT) 59-62.

Hou, C. and Wonglorsaichon, P. (2011). The Relationship Among Brand Awareness, Brand Image, Perceived Quality, Brand Trust, Brand Loyaltyand Brand Equity of Customer in China's Antivirus Software Industry. International Journal of Business and Economics, 2(1), 150-171.

Hsieh, H. Y. (2016). The relationship among consumer value, brand image, perceived value and purchase intention-a case of tea chain store in tainan city. In Proceedings of the Eighth AsiaPacific Conference on Global Business, Economics, Finance and Banking, 21-23.

Hyun, S. S. and Wansoo, K. (2011). Dimensions of brand equity in the chain restaurant industry. Cornell Hospitality Quarterly, 52(4), 429-437.

Ismail, A. R.; Nguyen, B. and Melewar, T. C. (2018). Impact of perceived social media marketing activities on brand and value consciousness: roles of usage, materialism and conspicuous consumption. International Journal of Internet Marketing and Advertising, 12(3), 233-254.

Išoraitè, M. (2018). Brand Image Theoretical Aspects. Integrated Journal of Business and Economics, 2(1), 116-122.

Jaiprakash, A. T. (2008). A conceptual research on the association between celebrity endorsement, brand image and brand equity. Journal of Marketing Management, 7(4), 54-64.

Jalilvand, M. and Samiei, N. (2012). The effect of electronic word of mouth on brand image and purchase intention: An empirical study in the automobile industry in Iran. Marketing Intelligence \& Planning, 30(4), 460-476. 
Jansen, B. J.; Zhang, M.; Sobel, K. and Chowdury, A. (2009). Twitter power: Tweets as electronic word-of-mouth. Journal of the American Society for Information Science and Technology, 60(11), 21692188.

Juma, M., \& Shaalan, K. (2021). Online Social Network Analysis for Cybersecurity Awareness. In Recent Advances in Intelligent Systems and Smart Applications, 585-614. Springer, Cham.

Kaiser, H. F. (1970). A second generation little jiffy. Psychometrika, 35(4), 401-415.

Kaiser, H. F. (1974). An index of factorial simplicity. Psychometrika, 39(1), 31-36.

Kale, P.; Singh, H. and Perlmutter, H. (2000). Learning and protection of proprietary assets in strategic alliances: Building relational capital. Strategic management journal, 21(3), 217-237.

Kapak, S. and Azizi S. (2013). Factors affecting overall brand equity: The case of Shahvand and chain store. Management \&Marketing, 7(1), 91-103.

Kaplan, A. M. and Haenlein, M. (2010). Users of the world, unite! The challenges and opportunities of Social Media. Business horizons, 53(1), 59-68.

Keller, K.L. (2001). Building Customer-Based brand equity: a blueprint for creating strong brands. Marketing Management, 10(2), 1519.

Keller, K.L. (2016). Reflections on customer-based brand equity: perspectives, progress, and priorities. AMS Review, 1(1), 1-16.

Kim, A. J. and Ko, E. (2012). Do social media marketing activities enhance customer equity? An empirical study of luxury fashion brand. Journal of Business research, 65(10), 1480-1486.

King, C. and Grace, D. (2009). Employee based brand equity: A third perspective. Services Marketing Quarterly, 30(2), 122-147.

Kokkomelis, K. (1995). Banking services for consumers (Retail Banking). Athens: Sakkoulas Publications. 
Krejcie, R. V., \& Morgan, D. W. (1970). Determining sample size for research activities. Educational and psychological measurement, 30(3), 607-610.

Kumar, A.; Bezawada, R.; Rishika, R.; Janakiraman, R. and Kannan, P. K. (2016). From social to sale: the effects of firm-generated content in social media on customer behavior. Journal of Marketing, $80(1), 7-25$.

Kumar, R. S.; Dash, S. and Purwar, P. C. (2013). The nature and antecedents of brand equity and its dimensions. Marketing Intelligence \& Planning, 31(2), 141-159.

Lai, F.; Griffin, M. and Babin, B. J. (2009). How quality, value, image, and satisfaction create loyalty at a Chinese telecom. Journal of business research, 62(10), 980-986.

Lambkin, M. and Muzellec, L. (2008) . Rebranding in the banking industry following mergers and acquisitions. International Journal of Bank Marketing, 26(5), 328-335.

Lau, G. T. and Lee, S. H. (1999). Consumers' trust in a brand and the link to brand loyalty. Journal of Market-Focused Management, 4(4), 341-370.

Lee, A.; Yang, J.; Mizerski, R. and Lambert, C. (2015). The strategy of global branding and brand equity. Routledge.

Lee, F. L.; Chen, H. T. and Chan, M. (2017). Social media use and university students' participation in a large-scale protest campaign: The case of Hong Kong's Umbrella Movement. Telematics and Informatics, 34(2), 457-469.

Lee, H. L. (2004). The triple-A supply chain. Harvard business review, 82(10), 102-113.

Li, M. W.; Teng, H. Y., \& Chen, C. Y. (2020). Unlocking the customer engagement-brand loyalty relationship in tourism social media: The roles of brand attachment and customer trust. Journal of Hospitality and Tourism Management, 44, 184-192. 
Li, C. and Hung, C. (2009). Marketing tactics and parents' loyalty: the mediating role of school image. Journal of Educational Administration, 47(4), 477-489.

Machi, L. A. and McEvoy, B. T. (2016). The literature review: Six steps to success. Corwin Press.

Mitra, S., \& Jenamani, M. (2020). OBIM: A computational model to estimate brand image from online consumer review. Journal of Business Research, 114, 213-226.

Mohan, M.; Jiménez, F. R.; Brown, B. P. and Cantrell, C. (2017). Brand skill: linking brand functionality with consumer-based brand equity. Journal of Product \& Brand Management 26 (5), 477-491.

Moisescu, O. I. and Allen, B. (2010). The Relationship Between Dimensions of Brand Loyalty. An Empirical Investigation among Romanian Urban Consumers. Management \& Marketing Challenges for Knowledge Society, 5 (4), 83-98.

Montoya, A. K. and Hayes, A. F. (2017). Two-condition within-participant statistical mediation analysis: A path-analytic framework. Psychological Methods, 22(1), 6-27.

Moorman, C.; Zaltman, G. and Deshpande, R. (1992). Relationships between providers and users of market research: The dynamics of trust within and between organizations. Journal of marketing research, 29(3), 314-328.

Morgan, R. M. and Hunt, S. D. (1994). The commitment-trust theory of relationship marketing. Journal of marketing, 58(3), 20-38.

Mourad, M.; Ennew, C. and Kortam, W. (2011). Brand equity in higher education. Marketing Intelligence \& Planning, 29(4), 403-420.

Murtiasih, S. and Siringoringo, H. (2013). How word of mouth influence brand equity for automotive products in Indonesia. ProcediaSocial and Behavioral Sciences, 81, 40-44.

Nazari, E.; Ghasemi, B. and Saeidi, S. S. (2015). Explaining the relationship between green brand image, green satisfaction and green trust and factors affecting on green brand equity. Bulletin of the Georgian National Academy of Sciences, 9(1), 487-494. 
Nguyen Viet, B., \& Nguyen Anh, T. (2021). The role of selected marketing mix elements in consumer based brand equity creation: milk industry in Vietnam. Journal of Food Products Marketing, 27(2), 72-88.

Nowak, L.; Liz, T. and Janeen, E.; Olsen (2002). Wowing the millennials: creating brand equity in the wine industry. Journal of Product \& Brand Management, 15(5), 316-323

Nunnally, J. C. (1978). Psychometric Theory: $2 d$ Ed. McGraw-Hill.

Odhiambo, G. and Hii, A. (2012). Key stakeholders' perceptions of effective school leadership. Educational Management Administration \& Leadership, 40(2), 232-247.

Padhy, S. K. and Sawlikar, R. K. (2018). The role of brand equity and brand awareness on consumers' purchase intention. International Journal of Business and Management Invention, 7(1), 12-16.

Pang, H. (2021). Identifying associations between mobile social media users' perceived values, attitude, satisfaction, and eWOM engagement: The moderating role of affective factors. Telematics and Informatics, 59.

Pappu, R. and Quester, P. (2006). Does customer satisfaction lead to improved brand equity? An empirical examination of two categories of retail brands. Journal of Product \& Brand Management, 15(1), 4-14.

Pinar, M.; Girard, T. and Eser, Z. (2012). Consumer-based brand equity in banking industry: A comparison of local and global banks in Turkey. International Journal of Bank Marketing, 30(5), 359-375.

Pitta, D. and Fowler, D. (2005). Online consumer communities and their value to new product developers. Journal of Product and Brand Management, 14(5), 283-291.

Plidtookpai, N., \& Yoopetch, C. (2021). The electronic Word-of-Mouth (eWOM) trustworthiness, brand image and other determinants of purchase intention of the middle class to luxury hotel services. Kasetsart Journal of Social Sciences, 42(1), 61-68. 
Pozin, I. (2014). Web page. Small Business Expert: Answers to Your Five Biggest Social Media Branding Questions. Forbes. Available at: http://www. forbes. com/sites/ilyapozin/2014/11/07/smallbusiness-expert-answers-to-your-five-biggest-social-mediabranding-questions.

Priem, R. L. (2007). A consumer perspective on value creation. Academy of Management Review, 32(1), 219-235.

Rambocas, M.; Kirpalani, V. M. and Simms, E. (2014). Building brand equity in retail banks: the case of Trinidad and Tobago. International Journal of Bank Marketing. 32(4), 300320.

Ray, A.; Pradip, K. B.; Shibashish, C. and Shilpee, A. D. (2021). Exploring the impact of different factors on brand equity and intention to take up online courses from e-Learning platforms, Journal of Retailing and Consumer Services, (59).

Ryu, K.; Han, H. and Kim, T. H. (2008). The relationships among overall quick-casual restaurant image, perceived value, customer satisfaction, and behavioral intentions. International Journal of Hospitality Management, 27(3), 459-469.

Sagynbekova, S.; Ince, E.; Ogunmokun, O. A.; Olaoke, R. O. and Ukeje, U. E. (2021). Social media communication and higher education brand equity: The mediating role of e-WOM. Journal of Public Affairs, 21(1), 1-9.

Sanny, L.; Arina, A.; Maulidya, R. and Pertiwi, R. (2020). Purchase intention on Indonesia male's skin care by social media marketing effect towards brand image and brand trust. Management Science Letters, 10(10), 2139-2146.

Sekaran, U., \& Bougie, R. (2016). Research methods for business: A skill building approach. John Wiley \& Sons.

Seo, E. J. and Park, J. W. (2018). A study on the effects of social media marketing activities on brand equity and customer response in the airline industry. Journal of Air Transport Management, 66, 36-41. 
Setini, M.; Asih, D.; Yasa, N. N.; Utami, N. M., \& Giantari, I. G. (2020). The role of brand image in mediating the influence of customer perceived value on the loyalty of Facebook users. Journal of Advanced Research in Dynamical and Control Systems, 12(5), 1284-1293.

Severi, E. and Ling, K. C. (2013). The Mediating Effects of Brand Association, Brand Loyalty, Brand Image and Perceived Quality on Brand Equity. Asian Social Science, 9(3), 125-137.

Severi, E.; Ling, K. C. and Nasermoadeli, A. (2014). The impacts of electronic word of mouth on brand equity in the context of social media. International Journal of Business and Management, 9(8), 84-96.

Shaalan, A.; Hegazy, A.; Tourky, M.; Elshaer, I. and Ashour, H. (2020). Understanding consumer-based brand equity and its antecedents in international and national banks in Egypt. Journal of Marketing Communications, 1-35.

Shabbir, M. Q.; Khan, A. A. and Khan, S. R. (2017). Brand loyalty brand image and brand equity: the mediating role of brand awareness. International journal of innovation and applied studies, 19(2), 416-423.

Shariq, M. (2019). Study of Brand Equity Formation in the Fast Moving Consumer Goods Category, Jindal Journal of Business Research, 8(1) 36-50.

Sheth, J. N.; Newman, B. I. and Gross, B. L. (1991). Why we buy what we buy: A theory of consumption values. Journal of business research, 22(2), 159-170.

Sheth, J. N. and Parvatlyar, A. (1995). Relationship marketing in consumer markets: antecedents and consequences. Journal of the Academy of marketing Science, 23(4), 255-271.

Siddiqui, M. S.; Siddiqui, U. A.; Khan, M. A.; Alkandi, I. G.; Saxena, A. K., \& Siddiqui, J. H. (2021). Creating Electronic Word of Mouth Credibility through Social Networking Sites and Determining Its Impact on Brand Image and Online Purchase Intentions in India. 
Journal of Theoretical and Applied Electronic Commerce Research, 16(4), 1008-1024.

Siegrist, M. (2021). Trust and risk perception: A critical review of the literature. Risk analysis, 41(3), 480-490.

Singh, S.; Singh, N.; Kalinić, Z., \& Liébana-Cabanillas, F. J. (2021). Assessing determinants influencing continued use of live streaming services: An extended perceived value theory of streaming addiction. Expert Systems with Applications, 168.

Simon, C. J. and Sullivan, M. W. (1993). The measurement and determinants of brand equity: a financial approach. Marketing Science, 12 (1), 28- 52.

Slambolchi, A.; Fathian, S. and Hamidi, K. (2015). The Effect of Elements of Service Marketing Mix on Brand Equity, from the Customers' Point of View (Case Study: Branches of Melli Bank in Hamadan). Arabian J Bus Manag Review, 5(6), 168-174.

Song, H.; Wang, J. and Han, H. (2019). Effect of image, satisfaction, trust, love, and respect on loyalty formation for name-brand coffee shops. International Journal of Hospitality Management, 79, 5059.

Stojanovic, I.; Andreu, L., \& Curras-Perez, R. (2018). Effects of the intensity of use of social media on brand equity. European journal of management and business economics. 27 (1), 83-100

Streiner, D. L.; Norman, G. R. and Cairney, J. (2015). Health measurement scales: a practical guide to their development and use. Oxford University Press, USA.

Swani, K.; George, R. M.; and Elizabeth, G. M. (2021). Social media services branding: The use of corporate brand names. Journal of Business Research 125 (2021) 785-797.

Sweeney, J. C. and Soutar, G. N. (2001). Consumer perceived value: The development of a multiple item scale. Journal of retailing, 77(2), 203-220. 
Taghipourian, M. J., \& Saberi, H. (2021). Investigating Behavioural Factors Affecting on Green Brand Equity in the Food Industry. Journal of Agricultural Economics and Development, 34(4), 357374.

Taleghani, M. and Almasi, M. (2011). Evaluate the factors affecting brand equity from the perspective of customers using Aaker's model. Kuwait Chapter of Arabian Journal of Business and Management Review, 1(4), 64-76.

Tavakol, M. and Dennick, R. (2011). Making sense of Cronbach's alpha. International Journal of Medical Education, 2, 53-55.

Tran, T. P.; Mai, E. S., \& Taylor, E. C. (2021). Enhancing brand equity of branded mobile apps via motivations: A service-dominant logic perspective. Journal of Business Research, 125, 239-251.

Veloutsou, C. (2015). Brand evaluation, satisfaction and trust as predictors of brand loyalty: the mediator-moderator effect of brand relationships. Journal of Consumer Marketing, 32(6), 405421.

Veloutsou, C.; Chatzipanagiotou, K., \& Christodoulides, G. (2020). The consumer-based brand equity deconstruction and restoration process: Lessons from unliked brands. Journal of Business Research, 111, 41-51.

Wang, Y.; Kim, J., \& Kim, J. (2021). The financial impact of online customer reviews in the restaurant industry: A moderating effect of brand equity. International Journal of Hospitality Management, 95.

Woodruff, R. B. (1997). Customer Value: The Next Source for Competitive Advantage. Journal of the Academy of Marketing Science, 25(2), 139-153.

Yasin, N. and Zahari, A. (2011). Does family and viral marketing have any effect on brand equity? Contemporary Marketing Review, 1(8), 113.

Yoo, B. and Donthu, N. (2002). The effects of marketing education and individual cultural values on marketing ethics of students. Journal of Marketing Education, 24(2), 92-103. 
Zahari, M.; Kamaruddin, M. S.; Muhammad, R. and Kutut, M. Z. (2011). Modernization, Malay matrimonial foodways and the community social bonding. International Scholarly and Scientific Research \& Innovation. 5(8), 1061-1071.

Zahoor, S. Z. and Qureshi, I. H. (2017). Social Media Marketing and Brand Equity: A Literature Review. IUP Journal of Marketing Management, 16(1), 47-64. 


\section{تحليل أثر كل من استخدام وسائل التواصل الاجتماعي والقيمة المدركة والثقة}

\section{بالعلامة والإتصالات الشخصية الإلكترونية على حقوق العلامة : الدور الوسيط \\ للصورة الذهنية للعلامة : دراسة تطبيقية على القطاع المصرفي المصري}

$$
\text { ملخص البحث باللغة العربية علاء الدين عباس علي }
$$

تهدف هذه الدراسة الي تحليل العوامل المؤثرة على حقوق العلامة بالتطبيق علي القطاع المصرفي المصري. ولتحقيق هذا الهدف

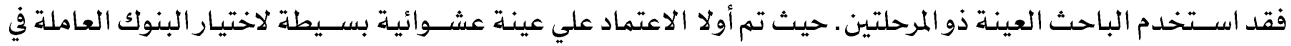

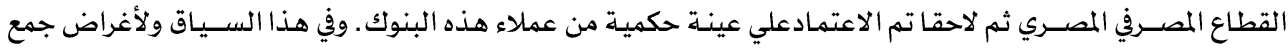
البيانات فقد تم استخدام قائمة استقصاء ذات الأسئلة المغلقة وكذلك اعتمد الباحث علي اسلوب المقابلة الشخصية حيث تم توزيع 400 قائمة اسـتقصـاء و تم اسـتخدام 390 منها و التي كانت صـالحة للتحليل الاحصـائي. وقد تم توظيف عدد من الأسـاليب الحصـائية مثل الاحصـاء الوصـفي ومعامل الارتباط والتحليل العاملي والتحليل المتعدد و ذلك لتحليل لتهليل البيانات.

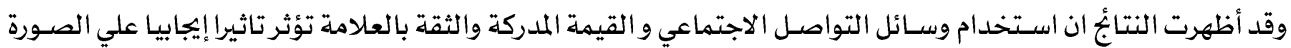

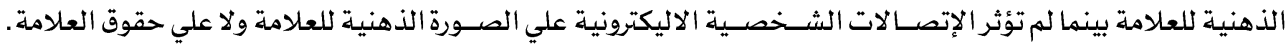

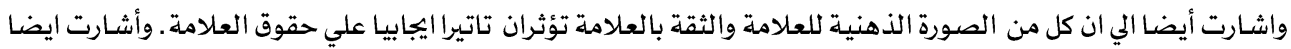
الي ان الصــورة الذهنية للعلامة تتوســط العلاقة بين كل من اسـتخدام وســائل التواصـل الاجتماعي والثقة في العلامـة

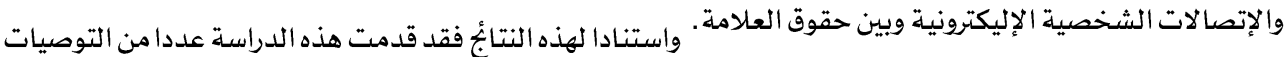

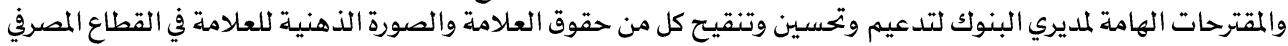

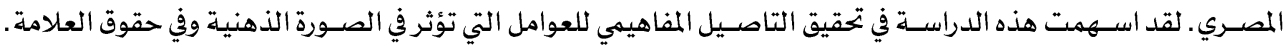
والتي تضـمنت كل من اسـتخدام وسـائل التواصل الاجتماعي والقيمة المدركة والإتصالات الشـضصية الإليكترونية والصورة الذهنية للعلامة. الكلمات الدالة : حقوق العلامة- الصـورة الذهنية للعلامة - اسـتخدام وسـائل التواصل الاجتماعي_ القيمة المدركة - الثقة بالعلامة- الإتصالات الشخصية الاليكترونية.

\section{Suggested Citation according to APA Style}

Ali, A. A. (2021). Analyzing the Effect of Social Media Use, Perceived Value, Brand Trust and Electronic Word of Mouth on Brand Equity: The Mediatiing Role of Brand Image: An Applied Study on Egyptian Banking Sector. Journal of Alexandria University for Administrative Sciences, Faculty of Commerce, Alexandria University 58(5), 1 - 59. 